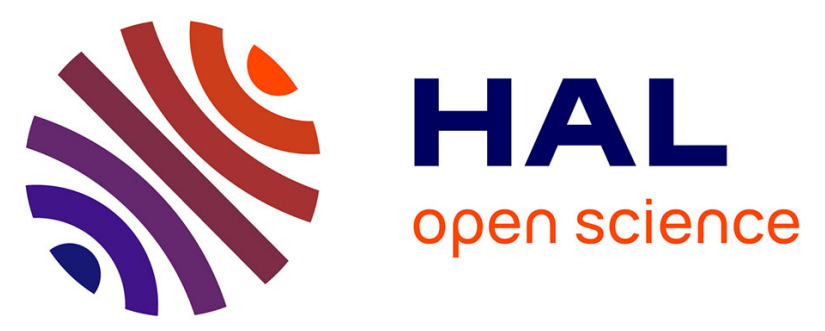

\title{
Molecular, isotopic and radiocarbon evidence for broomcorn millet cropping in Northeast France since the Bronze Age
}

\author{
Blandine Courel, Philippe Schaeffer, Pierre Adam, Estelle Motsch, Quentin \\ Ebert, Emile Moser, Clément Féliu, Stefano M. Bernasconi, Irka Hajdas, \\ Ertlen Damien, et al.
}

\section{To cite this version:}

Blandine Courel, Philippe Schaeffer, Pierre Adam, Estelle Motsch, Quentin Ebert, et al.. Molecular, isotopic and radiocarbon evidence for broomcorn millet cropping in Northeast France since the Bronze Age. Organic Geochemistry, 2017, 110, pp.13-24. 10.1016/j.orggeochem.2017.03.002 . hal-01800645

\section{HAL Id: hal-01800645 \\ https://hal-inrap.archives-ouvertes.fr/hal-01800645}

Submitted on 21 Aug 2020

HAL is a multi-disciplinary open access archive for the deposit and dissemination of scientific research documents, whether they are published or not. The documents may come from teaching and research institutions in France or abroad, or from public or private research centers.
L'archive ouverte pluridisciplinaire HAL, est destinée au dépôt et à la diffusion de documents scientifiques de niveau recherche, publiés ou non, émanant des établissements d'enseignement et de recherche français ou étrangers, des laboratoires publics ou privés. 
1 Molecular, isotopic and radiocarbon evidence for broomcorn millet

3 Blandine Courel ${ }^{\mathrm{a}}$, Philippe Schaeffer ${ }^{\mathrm{a}}$, Pierre Adam ${ }^{\mathrm{a}}$, Estelle Motsch ${ }^{\mathrm{a}}$, Quentin Ebert ${ }^{\mathrm{a}}$, Emile

4 Moser $^{\mathrm{a}}$, Clément Féliu ${ }^{\mathrm{b}, \mathrm{c}}$, Stefano M. Bernasconi ${ }^{\mathrm{d}}$, Irka Hajdas ${ }^{\mathrm{e}}$, Damien Ertlen ${ }^{\mathrm{f}}$, Dominique

$5 \quad$ Schwartz ${ }^{\mathrm{f}}$

6 a Université de Strasbourg, CNRS, CHIMIE, UMR 7177, F-67000 Strasbourg, France

$7 \quad$ b Inrap Grand-Est Sud, 67100 Strasbourg, France

8 c Université de Strasbourg, Université de Haute Alsace, CNRS, ArchIMèdE UMR 7044, F-

967000 Strasbourg, France

$10 \quad{ }^{\mathrm{d}}$ Geologisches Institut, ETH Zürich, Zürich, Switzerland

$11{ }^{\mathrm{e}}$ Laboratory of Ion Beam Physics, ETH Zürich, Zürich, Switzerland

$12 \mathrm{f}$ Université de Strasbourg, CNRS, Laboratoire Image, Ville, Environnement UMR 7362, F-

1367000 Strasbourg, France

14

15

16

*Corresponding author. Tel: +33 (0)3 68852805.

18

E-mail address: p.schaef@unistra.fr (Philippe Schaeffer). 
Molecular and isotopic investigation of lipids from soils filling several structures from an archaeological site located at Obernai (Alsace, NE France) has revealed the presence of miliacin, a triterpenoid marker from Panicum miliaceum (broomcorn millet), indicating that this cereal was cultivated at the site. The concentration profiles of miliacin within silos and its detection in other archaeological structures (e.g. Gaulish pit) suggest that miliacin did not originate from cereals stored in the silos but rather came from remains of millet from cultivated soils which filled the silos after they were abandoned. Furthermore, the ${ }^{14} \mathrm{C}$ age of miliacin isolated from a silo of the Second Iron Age was shown to be considerably older (Bronze Age) than the structure itself, revealing that the soil filling the silo therefore archived the molecular signature from past millet cropping, predating the digging of the silo. Thus, radiocarbon dating of the isolated miliacin allowed the timing of millet cropping to be determined, showing that it was established during the Bronze Age and the Roman Gaul period at Obernai. This is the first evidence of millet cultivation in Alsace dating back to the Bronze Age, bringing new perspectives on agricultural and past dietary practices in Eastern France. The combination of molecular studies and radiocarbon dating of individual lipids highlights the potential of hollow structures like silos and pits to act as "pedological traps", recording information on past vegetation cover or agricultural practices from the surface horizons of surrounding soils that filled these structures after abandonment. analysis; archaeometry; soil lipids; pedological traps. 


\section{Introduction}

When chemical analytical techniques were initially introduced to archaeological research during the middle of the $20^{\text {th }}$ century in a discipline referred to as archaeometry, the analysis mainly involved characterization of organic residues and materials related to artifacts such as pottery and jars (Condamin et al., 1976; Evershed et al., 1991; Charters et al., 1995; CharriéDuhaut et al., 2007), hafting material on flints (Boëda et al., 1996) or mummies (Connan, 1999; Buckley and Evershed, 2001). It is only more recently that lipid biomarkers in organic matter (OM) preserved in soils and sediments have been considered as archaeological archives (e.g. Bull et al., 2001; Egli et al., 2013; Motuzaite-Matuzeviciute et al., 2016). These lipids, which possess relative stability and resistance towards biodegradation (Eglinton and Logan, 1991; Lorenz et al., 2007), have been shown to have a potential as chemotaxonomic markers, allowing a link to be established between the preserved molecules ("chemical fossils") and their source organisms. Thus, lipid biomarkers, preserved within palaeosoils and sediments, may represent valuable tools for reconstructing palaeoenvironments or studying the evolution of landscapes through time (Trendel et al., 2010; Lavrieux et al., 2012; Ertlen et al., 2015), or investigating ancient dietary and agricultural practices (Bull et al., 1999; Jacob et al., 2008a; Sistiaga et al., 2014; Motuzaite-Matuzeviciute et al., 2016) or other human activities such as hemp retting (Lavrieux et al., 2013).

In studies dealing with soils, the lipid compartment of soil OM (SOM) is a result of the combination of old and refractory compounds mixed with more recent lipid inputs originating from the vegetation cover of the topsoil and introduced into deeper horizons by processes such as bioturbation, leaching or root penetration (Kögel-Knabner, 2002; Schmidt et al., 2011). Furthermore, the role of microorganisms living within the soil ecosystem has to be considered since they consume and produce part of the soil lipid components (Kögel-Knabner, 2002). The lipid content of SOM also depends strongly on the degree of preservation, which is related to 
different factors such as climate, biological activity, $\mathrm{pH}$, level of oxygenation, depth, mineralogy, or biochemical nature of the soil (Schmidt et al., 2011). As a result of the intense reshuffling of SOM and of the differential inherent persistence of the various lipid constituents of soils, interpretation of the lipid signatures from soils in terms of archaeological significance and their relationship with a chronological sequence is difficult to establish (Schwartz, 2012). In this respect, radiocarbon dating of SOM, lipid fractions and, in more rare instances, individual compounds from soils represents a powerful tool, potentially allowing, in the case of lipids, specific molecular signatures to be related to a chronological/historical context (e.g., Rethemeyer et al., 2005; Mendez-Milan et al., 2014). The tremendous advances in ${ }^{14} \mathrm{C}$ instrumentation during the last decade enable samples containing only minute amounts of carbon to be dated (e.g., Ingalls and Pearson, 2005; Birkholz et al., 2013; Gierga et al., 2016). In particular, the accelerator mass spectrometry (AMS) facility MICADAS (MIni CArbon DAting System), designed and developed at the ETH of Zurich, is equipped with a gas handling system and a gas ion source, allowing direct radiocarbon measurement of $\mathrm{CO}_{2}$ obtained via oxidation of very small samples, thereby giving access to radiocarbon dating of single compounds at the microgram scale (Ruff et al., 2007, 2010).

In the present study, we have investigated the content of lipid extracts (LEs) from soil material filling archaeological structures (silos, pit and latrines)near the city of Obernai (Alsace, NE France) using gas chromatography-MS (GC-MS) and GC-combustion- isotope ratio MS (GC$c$-IRMS), The investigation, which was originally aimed at determining the nature of the cereals/plants that could have been stored in the silos and potentially cultivated at the site, has revealed the presence of miliacin, a triterpenoid marker from Panicum miliaceum (broomcorn millet). Its occurrence and significance in terms of preservation and timing of millet cultivation is discussed, notably in the light of the stable carbon isotopic composition of lipids and radiocarbon dating of isolated miliacin. 


\section{Material and methods}

\subsection{Samples and archaeological context}

The archaeological site of Obernai (Alsace, NE France), spread over more than 7.5 hectares, was excavated in 2013 by the Institut National de Recherche Archéologique Préventive (INRAP) and has yielded numerous pieces of evidence for successive periods of human occupation dating back from the Neolithic period up to the beginning of the Middle Ages (Féliu et al., unpublished results). Among the structures unearthed, some corresponded to protohistoric silos deeply buried in the loess substrate (ca. 1-2.2 $\mathrm{m}$ high by ca. 1.5-2 m wide; Fig. 1 and Fig. S1 in Supplementary data). The silos, which were used for cereal storage, indicate that local agricultural activity occurred at the site. Some of the silos, dated from the Late Bronze Age (950-800 BC) and Second Iron Age (La Tène B, 400-260 BC), based on the typology of the ceramics in the soils filling the silos, were selected for biomarker analysis (Table 1). In addition, soil samples from one Neolithic silo (4600-4300 BC), one silo dated from La Tène D (150-30 $\mathrm{BC}$ ), as well as from a Gaulish pit encircling a farm and Roman Gaul latrines (end of the $2^{\text {nd }}$ centuary $\mathrm{AD}$ - beginning of the $3^{\text {rd }}$ centuary AD) were collected (Table 1 ). In the case of the silos, soil samples were collected at different depth levels within the apparent archaeological layers (ALs; Fig. 1 and Fig. S1 in Supplementary data). For comparison, the loess soils within which the silos were dug - named "loess substrate" (LS)- were sampled.

\subsection{Reference material from P. miliaceum}

Lipids from reference plant samples from P. miliaceum (broomcorn millet) provided by J. Jacob (Institut des Sciences de la Terre d'Orléans) were investigated. They consisted of seeds, stems, ears, leaves and roots obtained from millet cultivated in the frame of a detailed study of millet (Bossard et al., 2013). 
115 In order to avoid contaminations (e.g., phthalates), all commercial solvents were redistilled and 116 stored in glass bottles carefully cleaned and closed with an aluminium foil. Prior to use, all 117 glasswares were washed using water, acetone and finally with redistilled dichloromethane. All 118 equipements/supplies (pipettes, sand, silica, celilte) were washed with dichloromethane in a 119 Soxhlet. Once cleaned, the silica gel was activated at $120^{\circ} \mathrm{C}$. Each samples was kept in a freezer 120 at $-20^{\circ} \mathrm{C}$.

\subsection{Lipid extraction and fractionation (general procedure)}

122 Lipids from archaeological soils (ca. $500 \mathrm{~g}$ ) and from plant reference material were extracted 123 via sonication using $\mathrm{CH}_{2} \mathrm{Cl}_{2} / \mathrm{CH}_{3} \mathrm{OH}(1: 1, \mathrm{v} / \mathrm{v})$ followed by filtration of the supernatant through 124 celite and solvent removal under reduced pressure. In the case of archaeological soils, the yield 125 of lipid extract (LE) was low ( $\leq 0.04 \%$ of soil). Derivatization and fractionation of an aliquot of the extract was carried out after Schnell et al. (2014). Briefly, following acetylation of the

127 alcohol functionalities using an excess of $\mathrm{Ac}_{2} \mathrm{O}$ and $20 \mu \mathrm{l}$ of $N$-methylimidazole (catalyst) and 128 methylation of the carboxylic acids using $\mathrm{CH}_{2} \mathrm{~N}_{2}$ in $\mathrm{Et}_{2} \mathrm{O}$, the derivatized crude extract was 129 fractionated on a silica gel column into an apolar fraction eluted with $\mathrm{CH}_{2} \mathrm{Cl}_{2} / \mathrm{EtOAc}(8: 2$, v/v) 130 and a more polar fraction eluted with $\mathrm{CH}_{2} \mathrm{Cl}_{2} / \mathrm{CH}_{3} \mathrm{OH}(1: 1, \mathrm{v} / \mathrm{v})$, the latter not being investigated 131 further. After solvent extraction and prior to derivatization and fractionation, the propyl ester 132 of stearic acid was added as internal standard (IS) for quantitative analysis of miliacin.

\subsection{Lipid fractionation and derivatization for stable carbon isotope measurements}

\subsubsection{Fractionation of the $L E$}

135 An aliquot of the underivatized lipid extract adsorbed onto silica gel was fractionated using 136 activated silica gel column chromatography, eluting successively with cyclohexane $/ \mathrm{CH}_{2} \mathrm{Cl}_{2}$ 

with $n$ the number of carbon and $\delta$ the carbon isotopic ratio for derivatized compounds $(c d)$, the 156 derivative group added $(d)$ and the compound prior to derivatization $(c)$.

$\left(9: 1, v / v ; 1\right.$ dead volume, $\left.\mathrm{V}_{0}\right)$ to yield the hydrocarbon fraction, followed by $\mathrm{CH}_{2} \mathrm{Cl}_{2}\left(2 \times \mathrm{V}_{0}\right)$ to provide mainly miliacin, then $\mathrm{CH}_{2} \mathrm{Cl}_{2} / \mathrm{EtOAc}\left(9: 1, \mathrm{v} / \mathrm{v} ; 2 \times \mathrm{V}_{0}\right)$ for the $n$-alcohols and sterols. Finally, the most polar components, comprising carboxylic acids, were recovered with $\mathrm{CH}_{2} \mathrm{Cl}_{2} / \mathrm{CH}_{3} \mathrm{OH}\left(1: 1, \mathrm{v} / \mathrm{v} ; 2 \times \mathrm{V}_{0}\right)$.

\subsubsection{Derivatization}

The alcohol fraction, dissolved in $\mathrm{CH}_{2} \mathrm{Cl}_{2}$, was derivatized using pyridine (40 $\left.\mu \mathrm{l}\right)$ and bis- $(\mathrm{N}, \mathrm{O}$ trimethylsilyl)trifluoroacetamide (BSTFA; $70{ }^{\circ} \mathrm{C}, 2 \mathrm{~h}$ ), the $\delta^{13} \mathrm{C}$ composition of the trimethylsilyl (TMS) group having been determined previously. The solvent and excess reagent were removed under a stream of $\mathrm{N}_{2}$.

The polar fraction was reacted with $\mathrm{BF}_{3} / \mathrm{CH}_{3} \mathrm{OH}$ (the $\delta^{13} \mathrm{C}$ value of $\mathrm{CH}_{3} \mathrm{OH}$ being known) at $60{ }^{\circ} \mathrm{C}$ for $2 \mathrm{~h}$. The crude mixture was then transferred to a separatory funnel and the organic layer recovered after addition of distilled water and $\mathrm{CH}_{2} \mathrm{Cl}_{2}$. After removal of $\mathrm{CH}_{2} \mathrm{Cl}_{2}$ under reduced pressure, the derivatized extract was filtered through a small silica gel column/pipette using $\mathrm{CH}_{2} \mathrm{Cl}_{2}$, yielding the fatty acid (FA) methyl ester fraction.

The known isotopic composition of the added TMS group $\left(\delta^{13} \mathrm{C},-20.8 \%\right.$ ) and $\mathrm{CH}_{3} \mathrm{OH}$ group $\left(\delta^{13} \mathrm{C},-48.5 \%\right.$ ) allowed the $\delta^{13} \mathrm{C}$ value of the derivatized lipids to be corrected using the following equation (Rieley, 1994):

$$
\delta_{c}=\left(n_{c d} \delta_{c d}-n_{d} \delta_{d}\right) / n_{c}
$$


For radiocarbon dating and $\delta^{13} \mathrm{C}$ determination of SOM, an aliquot of the soil sample was decarbonated using $6 \mathrm{~N} \mathrm{HCl}$ at room temperature $(15 \mathrm{~min})$. After centrifugation, the supernatant was removed by pipetting and the residue rinsed with distilled water. The procedure was repeated until neutral and the residue oven-dried at $50{ }^{\circ} \mathrm{C}$.

\subsection{Isolation of miliacin}

The LE from selected samples (Table 1) was fractionated on a silica gel column, eluting successively with cyclohexane/ $\mathrm{CH}_{2} \mathrm{Cl}_{2}(8: 2), \mathrm{CH}_{2} \mathrm{Cl}_{2}$ and $\mathrm{CH}_{2} \mathrm{Cl}_{2} / \mathrm{CH}_{3} \mathrm{OH}$ (1:1), the secondeluted fraction being enriched in miliacin, as shown from GC-MS analysis (Fig. S2 in Supplementary data). This fraction was further purified and manually collected using high performance liquid chromatography (HPLC) with a Waters model 590 HPLC pump (mobile phase: $\mathrm{CH}_{2} \mathrm{Cl}_{2} / \mathrm{CH}_{3} \mathrm{OH}, 2: 8, \mathrm{v} / \mathrm{v}$; flow rate, $1 \mathrm{ml} / \mathrm{min}$ ), connected to an Agilent ZORBAX SBC18 column (25 $\mathrm{cm} \times 4.6 \mathrm{~mm}$ i.d., $5 \mu \mathrm{m}$, Agilent) and associated with a differential refractometer detector R401 (Waters Associates). After a control of the purity of the miliacin sample using GC flame ionization detection (GC-FID), a final clean up step using silica gel thin layer chromatography (TLC, $0.5 \mathrm{~mm} \mathrm{SiO}$ ) was sometimes required (samples 1330.AL2, $6,10)$ and carried out using cyclohexane/ $\mathrm{Me}_{2} \mathrm{CO}(98: 2)$ as developer, miliacin having a retention factor between 0.76 and 0.83 . The final purity was checked using GC-FID and GCMS (Fig. S2, Supplementary data).

\section{8. $G C-M S$}

GC-MS was carried out with a Thermo Trace gas chromatograph (Thermo Scientific) equipped with Tri Plus autosampler, a programmed temperature vaporizing (PTV) injector and a HP5MS column (30 m x $0.25 \mathrm{~mm}$ i.d. x $0.25 \mu \mathrm{m}$ film thickness) using He as carrier gas (constant $1.1 \mathrm{ml} / \mathrm{min}$ ). The temperature program used a gradient from $70{ }^{\circ} \mathrm{C}$ to $200{ }^{\circ} \mathrm{C}$ at $10{ }^{\circ} \mathrm{C} / \mathrm{min}$, then from $200{ }^{\circ} \mathrm{C}$ to $300{ }^{\circ} \mathrm{C}$ at $3{ }^{\circ} \mathrm{C} / \min$ (conditions A) or at $4{ }^{\circ} \mathrm{C} / \mathrm{min}$ (conditions B) followed by 
isothermal at $300{ }^{\circ} \mathrm{C}$ for $40 \mathrm{~min}$. The GC equipment was coupled to a Thermo TSQ Quantum mass spectrometer working in the electron ionization (EI) mode at $70 \mathrm{eV}$ and scanning $\mathrm{m} / \mathrm{z} 50$ to 700 . The data were investigated using the Xcalibur Software and mass spectra were compared with the NIST library and literature data (for MS data, see Table S1 in Supplementary data).

\section{9. $G C-F I D$}

GC-FID was carried out with a HEWLETT-PACKARD HP 6890 gas chromatograph equipped with an on-column injector, FID and a HP5-MS column (30 m x $0.32 \mathrm{~mm}$ i.d. x $0.25 \mu \mathrm{m}$ film thickness). The temperature program was: $70{ }^{\circ} \mathrm{C}-300{ }^{\circ} \mathrm{C}$ (held $40 \mathrm{~min}$ ) at $10{ }^{\circ} \mathrm{C} / \mathrm{min}$ ), with $\mathrm{H}_{2}$ as carrier gas (constant $2.5 \mathrm{ml} / \mathrm{min}$ ). The temperature of the detector was $310^{\circ} \mathrm{C}$.

\subsection{Elementar analysis-combustion-isotope ratio mass spectrometry (EA-c-IRMS)}

Bulk carbon isotope composition $\left(\delta^{13} \mathrm{C}\right)$ of SOM was determined using an Elementar Vario Micro Cube equipped with thermal conductivity detection and coupled to an Isoprime visION stable isotope ratio mass spectrometer. Homogenized decarbonated soil samples were weighted into $\mathrm{Sn}$ capsules using a microbalance $\left(2 \times 10^{-2} \mathrm{~g}\right.$; CPA26P Sartorius). The capsules were individually introduced into a combustion furnace $\left(950^{\circ} \mathrm{C}\right)$ with an excess of $\mathrm{O}_{2} . \mathrm{CuO}$ was used as the oxidation catalyst and $\mathrm{He}$ was the carrier gas. Water was removed with a $\mathrm{P}_{2} \mathrm{O}_{5}$ trap and $\mathrm{CO}_{2}$ was separated with a purge and trap desorption column. Ion currents $(\mathrm{m} / \mathrm{z} 44,45,46)$ were measured continuously for $\mathrm{CO}_{2}$ using triple Faraday cups connected to high gain amplifiers. Reference pulse peaks of laboratory $\mathrm{CO}_{2}$ gas were calibrated against the international standards IAEA C3 $\left(\delta^{13} \mathrm{C}=-24.91(0.49) \%\right)$ and IAEA $\mathrm{C} 4\left(\delta^{13} \mathrm{C}=-23.96(0.62) \%\right.$ ) for $\mathrm{CO}_{2}($ IAEA, Vienna, Austria). The isotopic composition of samples was normalized to a calibrated IVA soil standard $\left(1.65 \% \mathrm{C}, \delta{ }^{13} \mathrm{C}=-26.66 \%\right)$ measured under identical conditions every 10 samples. 
205 The stable isotope ratio values are given in the delta notation with respect to the standard Vienna 206 Pee Dee Belemnite (VPDB).

GC-c-IRMS measurements were carried out with a Trace GC Ultra gas chromatograph equipped with an on-column injector, Agilent HP5-MS column (30 m x 0.25 mm i.d. x $0.1 \mu \mathrm{m}$ film thickness), GC Isolink II conversion unit, comprising a combustion oven (at $1000{ }^{\circ} \mathrm{C}$ ), a

211 ConFlo IV interface system and a Delta V Plus mass spectrometer (Thermo Scientific). The 212 temperature program was: $80^{\circ} \mathrm{C}-310^{\circ} \mathrm{C}\left(4^{\circ} \mathrm{C} / \mathrm{min}\right)-$ isothermal at $310{ }^{\circ} \mathrm{C}(40 \mathrm{~min})$. Each 213 analysis was repeated $3 \mathrm{x}$ and the mean standard deviation was calculated.

214 Before and after each triplicate, the carbon isotopic composition of a certified $n$-alkane mixture

215 (Type A5; Arndt Schimmelmann, Department of Geological Sciences, Biogeochemical 216 Laboratories, Indiana University, USA) was measured and used for calibration. The stability of 217 the measurements was checked using pulses of reference $\mathrm{CO}_{2}$ prior ( 5 pulses) and after (3 218 pulses) each run. The data were analyzed using Isodat 3.0 software. For correction of the $\delta^{13} \mathrm{C}$ 219 values of derivatized lipids, see Section 2.4

\subsection{Radiocarbon dating from $A M S$}

The ${ }^{14} \mathrm{C}$ measurements were performed in the Laboratory of Ion Beam Physics (ETH of Zurich, Switzerland) using the MICADAS AMS equipment (Synal et al., 2007) which possess a gas

223 handling system adapted for very small volumes ( $\mu$ g level; Ruff et al., 2010; Wacker et al., 224 2010a,b). Samples containing $>100 \mu \mathrm{g} \mathrm{C}$ as well as phthalic acid (blank analyses) were 225 graphitized using the automated AGE system (Wacker et al., 2010a). Small samples (i.e isolated 226 miliacin) were oxidized (combusted) and the resulting $\mathrm{CO}_{2}$ was transferred to quartz tubes for 227 analysis in the ion source (Ruff et al., 2007, 2010). A standard (oxalic acid II) was prepared and 
measured together with the samples. ${ }^{14} \mathrm{C} /{ }^{12} \mathrm{C}$ and ${ }^{13} \mathrm{C} /{ }^{12} \mathrm{C}$ isotopic ratios were determined using the MICADAS dating system (Synal et al., 2007; Wacker et al., 2010b). Measured ${ }^{14} \mathrm{C} /{ }^{12} \mathrm{C}$ values of samples were corrected for the blanks and isotopic fractionation $\left(\delta^{13} \mathrm{C}\right.$, determined with graphite or $\mathrm{CO}_{2}$ ), ${ }^{14} \mathrm{C}$ age values were calculated following Stuiver and Polach (1977). Calibrated ages were established using the atmospheric calibration curve IntCal13 reported by Reimer et al. (2013).

\section{Results and discussion}

\subsection{Evidence from miliacin for millet cropping}

Overall, at the Obernai site, the lipid signatures from the soils sampled within the silos (e.g. silo 1330; Fig. 2a), in the loess substrate and in the Gaulish pit (structure 1001; Fig. 2b,c) showed the same global lipid assemblage, comprising $n$-alkyl lipids (alkanes, FAs and alcohols), sterols and triterpenoids. $n$-Alcohols in the $\mathrm{C}_{22}-\mathrm{C}_{32}$ range were predominant and showed an even carbon number predominance, with $\mathrm{C}_{26}$ prevailing. Even numbered $n$-acids from higher plants in the $\mathrm{C}_{20}-\mathrm{C}_{32}$ range were systematically dominated by $\mathrm{C}_{24}-\mathrm{C}_{30}$, whereas $n$-alkanes with an odd/even predominance were generally dominated by $\mathrm{C}_{29}$ and $\mathrm{C}_{31}$. These straight chain distributions reflect the contribution from terrestrial plants, possibly from grassland plants (e.g. van Bergen et al., 1997; Trendel et al., 2010). Within most silos and in the Gaulish pit and latrines (Fig. 2), $\mathrm{C}_{29}$ sterols (1-3; numbers refer to structures in Appendix A), as well as a series of pentacyclic triterpenoids comprising glutinone (4), taraxerol (5), germanicol (6), lupeol (7), friedelin (8), $\alpha$-amyrin (9), bauerenyl acetate (10) and betulin (11), again point toward a predominant higher plant contribution (e.g. Lavrieux et al., 2011; Schnell et al., 2014). Closer examination of the triterpene assemblage from the soil samples filling some of the archaeological structures (silos, Gaulish pit, latrines; Fig. 2) revealed the presence of an early eluting triterpenoid identified as olean-18-en-3 $\beta$-ol methyl ether, i.e. miliacin- (12), based on 
its mass spectrum (Jacob et al., 2008b). This rather rare compound belongs to the series of pentacyclic triterpene methyl ethers (PTMEs) generally restricted to Gramineae (Ohmoto et al., 1970; Jacob et al. 2005). The presence of a methoxy group at C-3 has been shown to give a high resistance of PTMEs towards biodegradation, which additionally display antibacterial and antifungal properties (Jacob et al., 2005). This enhanced resistance allowed miliacin to be detected within palaeosoils investigated in an archaeological context (Motuzaite-Matuzeviciute et al., 2016). As shown by Jacob et al. (2008b) and Bossard et al. (2013), miliacin is closely linked to its specific precursor organism, Panicum miliaceum (broomcorn millet or common millet), where it occurs in the different plant compartments (seeds, stems, ears, leaves, roots), but is more concentrated by far in the grains. In contrast, it is completely absent among the triterpenoids from another widespread millet species, Setaria italica (foxtail millet; Bossard et al., 2013), allowing a distinction to be made at the molecular level between these two cereal species. Given this specificity, detection of millet within most of the soils filling the silos at the Obernai site is of particular interest. Its presence indeed suggests that common millet was cultivated at the site, with the possibility that this cereal was stored within the silos (see below). Furthermore, other minor triterpenoids also biosynthesized by the broomcorn millet - although in much lower quantity than miliacin - comprising isosawamilletin (13) - another PTME together with germanicol (6) and friedelin (8) (Bossard et al., 2013), co-occur with miliacin in the archaeological soils (Fig. 2a). Another piece of evidence confirming that millet was present at the site was recently obtained from carpological studies (Durand, unpublished results) which led to the identification of a few carbonized and mineralized grains of $P$. miliaceum within some silos. However, the low number of grains $(<10)$ generally identified in the different silos except in the case of silo 1763 in which 172 remnants of carbonized grains were identified in the lower archaeological layer (AL2; Fig. 1) - did not allow a correlation to be established between the occurrence of cereal remains in the silos and the presence of miliacin in the 
corresponding soil samples. Some silos indeed showed a complete absence of millet grains, but where miliacin was detected. Finally, stable carbon isotopic studies provided additional evidence indicating that miliacin found at Obernai and common millet are closely linked. The $\delta^{13} \mathrm{C}$ value of miliacin was determined at ca. $-21.5 \%$ (Table 2 ), in the same range as the values reported for miliacin isolated from reference millet grains or extracted from soils $(-21.5$ to 23.5\% ; Jacob et al., 2008b). These values, around $-20 \%$, are much less ${ }^{13} \mathrm{C}$-depleted than those generally determined in the case of lipids from temperate region plants which generally use the $\mathrm{C}_{3}$ carbon fixation pathway. This pathway leads to lipids having $\delta^{13} \mathrm{C}$ values between -30 and 40\%o (e.g. Collister et al., 1994; Chikaraishi et al., 2004; Bi et al., 2005; Chikaraishi and Naraoka, 2006), whereas $P$. miliaceum has a $\mathrm{C}_{4}$ metabolism (Jacob et al., 2008b). The latterleads to the biosynthesis of biomass (including lipids) less ${ }^{13} \mathrm{C}$-depleted (e.g., Chikaraishi et al., 2004; Bi et al., 2005; Chikaraishi and Naraoka, 2007; Mendez-Millan et al., 2014). In the case of miliacin detected at the Obernai site, the $\delta^{13} \mathrm{C}$ composition is in good agreement with a $\mathrm{C}_{4}$ plant source, confirming that it most likely originates from P. miliaceum (Jacob, 2008b).

\subsection{Role of archaeological pits as traps for lipid biomarkers}

As determined above, based on molecular, isotopic and carpologic grounds, millet seemed to be present and likely cultivated as a cereal at the site of Obernai. Given the presence of miliacin in most of the silos, it can be proposed, at first glance, that millet was stored in the silos, at least in those dating from the Middle Bronze Age (silo 1763) up to the Second Iron Age (silos 1330, 1508,1513 and 1521). If this were the case, miliacin would represent the molecular remains of the grains originally stored in the silos and recovered for consumption. One would then expect to find the highest concentration of miliacin at the bottom of the silos, and eventually trace amounts (if any) in the AL from the middle and upper soil filling. To test this hypothesis, 
quantitative analysis of miliacin by way of GC-FID was performed on AL from silo soil samples at different filling depths. Except in the case of silo 1817 (Neolithic), in which no miliacin was found (see discussion below), all LE from the silo soils contained miliacin in high relative amount (Fig. 3), whereas it was absent - or present at trace level - in the loess substrate. This strongly suggests that the presence of miliacin is closely associated with the silos. However, miliacin concentration profiles within the different silos showed high variability. In silos 1513 , 1508 and 1763, the highest concentration was at the bottom, whereas the opposite was the case for silos 1521 and 1781 (Fig. 3). There was also an intermediate situation, with the highest concentration in the middle sampling levels (silo 1330). These unexpected concentration profiles suggested that miliacin (and hence, millet cultivation) was closely associated with the surface horizons of surrounding soils that filled the silos rather than indicating that millet was the cereal stored in the silos. This apparent disjunction between the function of an archaeological structure (cereal storage in silos, in the present case) and its lipid content is also illustrated by the presence of miliacin in the LE from a Gaulish pit sample - an archaeological structure not related to any agricultural practices - from the same archaeological site (Fig. 2c).

In conclusion, with respect to the presence of millet at this archaeological site, we propose that the silos, as well as the Gaulish pit, played the role of "archaeological traps", in the sense that these structures, once abandoned, were filled quickly (intentionally or not) with surrounding soil horizon(s), the latter having been "sealed" within these structures and having kept the record of past agricultural practices. This conclusion would be in line with the concept of "pedological trap" recentlydeveloped (e;g., Ertlen et al., 2013; Lauer et al., 2013).

\subsection{Evidence from ${ }^{14} \mathrm{C}$ dating for millet cropping dating back to the protohistoric and antic} periods 
324 In order to constrain the timing of millet cultivation/consumption at the Obernai site, ${ }^{14} \mathrm{C}$ dating 325 measurements were undertaken on SOM, LE, isolated miliacin from a series of selected 326 archaeological samples and millet grains from silo 1763 (Féliu, 2017). Among them, two silos 327 were chosen as representative of distinct periods of occupation of the site, based on ceramology 328 dating (Table 1). Silo 1763 represents the oldest structure in which miliacin was detected (see 329 above) and is dated from the Late Bronze Age (950-800 BC, corresponding to ca. 2900-2750 330 yr BP), whereas silo 1330 was selected to cover the Second Iron Age (400-260 BC, ca. 2350$3312210 \mathrm{yr} \mathrm{BP})$. A third, more recent structure (4564) from the site - not discussed in detail here 332 corresponding to latrines from the Roman Gaul period (end of the $2^{\text {nd }}$ - beginning of the $3^{\text {rd }}$ 333 century AD, ca. 1750-1800 yr BP), was also shown to contain exceptionally high amounts of 334 miliacin (Fig. 2d), which was isolated from AL8 and ${ }^{14} \mathrm{C}$ dated (Table 3).

335 Given the low amount of OM generally in these loess soil samples (TOC $<0.1 \%$ ), radiocarbon 336 dating measurements were carried out using the AMS instrument MICADAS. Pure miliacin 337 from silos 1330 and 1763 and Roman-Gaul latrines 4564 was obtained from the LE from AL 338 (Table 3) using a combination of separation steps involving silica gel liquid chromatography, 339 reversed phase HPLC and thin layer chromatography (Section 2.6). Using our isolation protocol, 340 miliacin was recovered in the range of $15 \mu \mathrm{g}$ to $300 \mu \mathrm{g}$, with a purity between $80 \%$ and $>90 \%$ 341 (determined from GC, Fig. S2 in Supplementary data), the co-occurring compounds comprising 342 mainly olean-13(18)-en-3 $\beta$-ol methyl ether (isosawamilletin, 13) another triterpenoid from 343 millet (Bossard et al., 2013). Despite the rather low quantity isolated in most cases, ${ }^{14} \mathrm{C}$ age 344 values could be determined as ${ }^{14} \mathrm{C}$ age $\mathrm{BP}$ and calibrated ${ }^{14} \mathrm{C}$ age $\mathrm{BC}$ (Table 3 and Table S2 for 345 the complete data set).

346 In the case of silo 1330 (Second Iron Age), the ${ }^{14} \mathrm{C}$ age of SOM from a soil sample collected 347 within AL6 located at mid-depth of the silo (Fig. 1) was measured at $3042 \mathrm{yr}$ BP, slightly older 348 than the lipid extract from the same soil sample by ca. $200 \mathrm{yr}$ (Fig. 4 and Table 3). The age of 
miliacin isolated from this soil sample, as well as that from miliacin from two AL located at the bottom and top of the same silo (AL2 and AL10) showed globally the same age of ca. 3000$3200 \mathrm{yr}$ BP (Fig. 4 and Table 3). Interestingly, the ${ }^{14} \mathrm{C}$ age of miliacin from the second silo (silo 1763, Late Bronze Age) was similar to that of miliacin from silo 1330 (Second Iron Age). These values, all close to that determined for SOM from AL6 (silo 1330) and AL2 (silo 1763), are clearly older than the age of silo structure 1330 as determined from ceramology (ca. 400-260 BC), indicating that miliacin (and hence, millet) was not contemporaneous with the use of the silos for cereal storage. In fact, in all cases, the age of miliacin corresponds to the Bronze Age, between 3994 and 2776 yr BP, whereas silos 1763 and 1330 were probably in use between 950$800 \mathrm{BC}$ (end of the Bronze Age) and 400-260 BC (second Iron Age), respectively.

The age difference between the archaeological structure and miliacin was particularly marked with silo 1330, with a difference $>600 \mathrm{yr}$. Moreover, the similarity in the age of miliacin from the three archaeological layers sampled within silo 1330 indicates that the structure was filled quickly with the same soil after abandoning, whatever the archaeological layers considered. The situation was different with silo 1763 , for which miliacin had almost the same (or slightly older) age (Fig. 4) than the silo dated from the end of the Bronze Age, a period during which the cereal was cultivated and likely stored in silos. A confirmation that millet was consumed at this time period was indeed attested to from the presence, at the bottom of the structure (AL2;

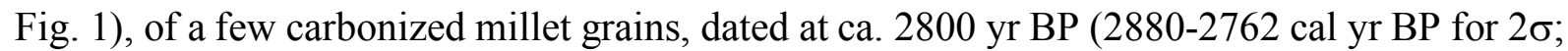
Féliu, 2017).

In conclusion, based on quantitative and ${ }^{14} \mathrm{C}$ dating measurements, it appears that the presence of miliacin cannot be interpreted as evidence of cereal storage in the silo structures, contrary to what was initially envisaged, but rather reflects the existence of millet cultivation predating the digging of the silos, except silos 1817 (Neolithic, predating millet cropping), and 1763 (Late Bronze Age, contemporaneous with millet cropping). Once abandoned, the emptied silos were 
filled rapidly with the surface horizons of surrounding soils and thus acted as "pedological traps" for the soils that were used for millet cultivation ca. $3 \mathrm{kyr}$ BP ago, sealing and preserving their SOM content, including lipids. A search for biomarkers indicative of the contribution of other types of cereals, such as wheat or barley, such as e.g., alkyl resorcinols (Appendix A; Hengtrakul et al., 1991; Seitz, 1992; Ross et al., 2003, 2004), was unsuccessful. Indeed, there was no evidence for such an occurrence from the lipid extracts, whereas these cereals could be detected in the form of carbonized grains from carpological studies, found within some silos dated from the Late Bronze Age and La Tène (Durand, unpublished results). The absence of alkyl resorcinols could be due to a low preservation potential, as these compounds have been shown to be easily degraded upon processes like fermentation or heating (Winata and Lorenz, 1997), possibly explaining why they have never been reported in archaeological studies.

The case of the Roman Gaul latrine structure 4564 is sharply different from that of the silos, since an almost identical ${ }^{14} \mathrm{C}$ age was obtained for the LE, SOM and miliacin, this age being also in good agreement with that of the structure itself, as determined independently from ceramology. In this case, miliacin consumption (and/or millet cultivation) could be unambiguously correlated with the Roman Gaul period, and was confirmed from carpological studies showing the presence - although in very low amount - of mineralized millet grains within the latrine structure (Durand, unpublished results).

\section{4. $C_{4}$ vs. $C_{3}$ plant input using the $\delta^{13} C$ record of n-alkyl lipids}

Several studies have used the $\mathrm{C}$ isotopic changes of SOM or lipids within soils to trace back $\mathrm{C}_{3}$ vs. $\mathrm{C}_{4}$ vegetation change and to study the turnover of SOM induced by the vegetation change (e.g. Schwartz, 1991; Mariotti and Peterschmitt, 1994; Pessenda et al., 1998; Wiesenberg et al., 2004; Quénéa et al., 2006; Mendez-Millan et al., 2014). In the present study, the stable carbon isotopic composition of some straight chain lipids ( $n$-alkanes, FAs and alcohols) from selected 
soil samples was measured in order to determine if $n$-alkyl inputs from a $\mathrm{C}_{4}$ plant (i.e., millet) could be detected on the basis of these compounds. It appeared that the $n$-alkanes in the LE from the soils filling silos 1330, 1781 and 1508 showed $\delta^{13} \mathrm{C}$ values between -29.9 and $-35.5 \%$ (Table 2) typical for $\mathrm{C}_{3}$ plants ( Bi et al., 2005; Mendez-Millan et al., 2014). The same held for the FAs - when they could be measured - with $\delta^{13} \mathrm{C}$ values ranging between $-31.6 \%$ and $-37.0 \%$ (Table 2). Similar values were obtained in the case of the $n$-alcohols $\left(\delta^{13} \mathrm{C}\right.$ between $-31.4 \%$ and $-36.8 \%$; Table 2). These values highlight an almost pure $C_{3}$ isotopic signature. This was confirmed by the $\delta^{13} \mathrm{C}$ values of bulk SOM in selected samples (silo 1330 AL 2, 6, 10 and Roman latrines $4564 \mathrm{AL} \mathrm{4,} 8$ 9), which all fell in the rather narrow range of $-25.5 \% \pm 1$, corresponding to a $\mathrm{C}_{3}$ source (e.g. Balesdent et al., 1987; Schwartz, 1991; Beniston et al., 2014; Chikaraishi et al., 2004). Interestingly, the $\delta^{13} \mathrm{C}$ values of SOM from the corresponding surrounding soils gave the same isotopic signature, indicating that the $\mathrm{C}_{4}$ contribution detected at the molecular level (i.e. the presence of miliacin) could not be observed from bulk carbon analysis.

For the lipids, the case of 1-dotriacontanol $\left(n-\mathrm{C}_{32}\right)$ was slightly different from the other straight chain compounds, with a $\delta^{13} \mathrm{C}$ value enriched in ${ }^{13} \mathrm{C}$ by ca. $2-4 \%$ compared with the lower $n$ alcohol $\mathrm{C}_{26}-\mathrm{C}_{30}$ homologues (Table 2), suggesting a mixed contribution from both $\mathrm{C}_{3}$ and $\mathrm{C}_{4}$ plants. This is the case in all the silo samples containing miliacin and, interestingly, not the case for the loess substrate samples and for the Neolithic silo 1817, the sole silo devoid of evidence for millet occurrence (Table 2). It turns out that our study of common millet highlighted the particular abundance of 1-dotriacontanol in the leaves (Fig. S3 in Supplementary data) in accordance with the literature (up to $80 \%$ of summed free $n$-alcohols according to Tulloch, 1982). Consequently it could be envisaged that part of this compound coming from millet was preserved, whereas the $\mathrm{C}_{4} \delta^{13} \mathrm{C}$ signature of the other straight chain lipids, originally less 
abundant in millet, was progressively replaced with the $\mathrm{C}_{3} \delta^{13} \mathrm{C}$ signature of the succeeding vegetation.

In conclusion, most of the soil lipids, as well as the $\mathrm{SOM}$ showed a clear $\mathrm{C}_{3}$ plant signal, most likely reflecting the contribution from Gramineae. In the soils filling the silos, this predominant contribution was accompanied by a small signal from a $\mathrm{C}_{4}$ plant source, mainly highlighted by the triterpenoid miliacin and its $\delta^{13} \mathrm{C}$ signature, but also, to a minor extent, by the $\delta^{13} \mathrm{C}$ signal of 1-dotriacontanol.

\subsection{Extent of millet cropping inferred from stable carbon isotopes and ${ }^{14} \mathrm{C}$ dating}

The low contribution of lipids from millet to the $n$-alkyl lipid pool, as inferred from stable carbon isotopes, could be explained on one hand by a limited contribution from millet biomass to the SOM vs. that of $\mathrm{C}_{3}$ plants (i.e. limited millet cropping). Such a situation might be encountered if millet cropping were not quantitatively important in terms of surface cultivation or of duration of cultivation. In this case, the molecular signature of $n$-alkyl lipids from millet would be diluted with that from the predominating surrounding $C_{3}$ vegetation (natural or cultivated in parallel with millet). Furthermore, the predominant $\mathrm{C}_{3}$ vegetation that either preceded or succeeded millet cropping might also be responsible for the observed isotopic signature for the filling soils, a signature which was "sealed" within the silos after they were abandoned.

In addition, irrespective of the importance of the initial contribution of millet biomass to SOM, the stable carbon isotopic composition of straight chain lipids and miliacin within silo 1330 but probably also the other silos from the Iron Age - could be interpreted in terms of lipid turnover associated with a vegetation change from a mixed $C_{3}+C_{4}$ vegetation to a pure $C_{3}$ vegetation cover in the light of the radiocarbon dating results. Indeed, there is a time difference of several centuries between the age of miliacin (Bronze Age) and that of the silo (Iron Age) in 
which miliacin was detected (Table 3). This difference implies that, following millet cultivation, the soils underwent vegetation change before being trapped within the abandoned silo, this vegetation being made up of $\mathrm{C}_{3}$ plants (e.g. pasture or cereals like wheat, barley, ...) based on the $\delta^{13} \mathrm{C}$ values of the lipids and SOM (see above). The period during which the $\mathrm{C}_{4}$ plus $\mathrm{C}_{3}$ vegetation lasted cannot be determined, the radiocarbon age of miliacin corresponding to an average age resulting from more ancient and more recent contributions, with unknown limits for the beginning and end of this cereal crop. The progressive replacement of millet cropping resulted in the "dilution" of the millet molecular and isotopic signatures by those of the newly occupying $\mathrm{C}_{3}$ plants. For each molecular structure considered, the replacement rate would depend on one hand on the relative contribution of millet origin vs. $\mathrm{C}_{3}$ plants and on the other hand on the relative stability of each structure considered. For instance, miliacin, which has a particularly stable structure due to the presence of the methoxy group at C-3, and which is not biosynthesized by $C_{3}$ plants native to temperate regions (Bossard et al., 2013), would keep its typical $\mathrm{C}_{4}$ isotopic signature (i.e., no isotopic "dilution" given the absence of miliacin inputs from a $\mathrm{C}_{3}$ source). By contrast, in the case of straight chain lipids, the progressive degradation of the $\mathrm{C}_{4}$ source, together with the constant new input from straight chain lipids of $\mathrm{C}_{3}$ origin, would result in the progressive "dilution" of the molecular and isotopic signature of lipids of $\mathrm{C}_{4}$ origin. Such a situation has some analogy with that reported by Mendez-Millan et al. (2014), who investigated the evolution of the stable carbon isotopic composition of lipids from a soil during a $30 \mathrm{yr}$ chronosequence during which savannah (in this case dominated by $\mathrm{C}_{4}$ plants) was replaced by an eucalyptus plantation (a $\mathrm{C}_{3}$ plant). Here, the molecular and isotopic fingerprints from triterpenoid methyl ethers from savannah vegetation was only little affected by the vegetation change, whereas the isotopic composition of the straight chain lipids was progressively shifted towards more negative $\delta^{13} \mathrm{C}$ values, as expected from such a vegetation change. Based on stable carbon isotopes, it was notably determined that $>30 \%$ of the $n-\mathrm{C}_{27}$ 
471 alkane originated from the newly installed $\mathrm{C}_{3}$ plant source after $30 \mathrm{yr}$ of eucalyptus coverage.

472 Conversely, in the case of a vegetation change from $\mathrm{C}_{3}$ (wheat) to $\mathrm{C}_{4}$ (maize) plants, the $\delta^{13} \mathrm{C}$

473 values from soil constituents move towards less ${ }^{13} \mathrm{C}$-depleted values (Lichtfouse et al., 1995).

\subsection{Timing of millet cropping at the site of Obernai}

Contrary to the protohistoric silos described above, the filling soil from silo 1817 (MidNeolithic, 4600-4300 BC) was devoid of miliacin, suggesting that millet was not cultivated at that time period. By contrast, structure 4564 (Roman Gaul period), corresponding to latrines, contained very high amounts of miliacin, having the same radiocarbon age (Table 3 ) as that of the structure. In this case, it seems that millet was consumed and likely cultivated locally at this period, in agreement with the literature (Reddé et al., 2005; Vandorpe and Wick, 2015).

The radiocarbon measurements allowed establishing that millet was cultivated during the Bronze Age and the Roman Gaul period at least, which makes sense in the light of the historical and archaeological data for the history of this cereal. In Alsace (NE France), where agricultural practices can be traced back down to ca. 4500 BC (Ruas and Marinval, 1991), very few archaeological studies report the detection of carpologic remains from millet during Protohistoric times, with only limited mention of its cultivation and consumption during the Iron Age (Wiethold, 2000; Bataille, 2014; Goude et al., 2015). This is also the case during the Roman period (Reddé et al., 2005; Vandorpe and Jacomet, 2011; Vandorpe and Wick, 2015), and the present study of the site of Obernai brings complementary information regarding millet cropping at the local and national scale during this period.

From an archaeological viewpoint, millet finds its origin in China where it was domesticated since the VII ${ }^{\text {th }}$ millenium BC (Laporte, 2001; Fuller, 2007; Lu et al., 2009). For instance, it has been recently shown that, in China, millet grains were fermented with other cereal grains to prepare beer (Wang et al., 2016). Later, millet culture began to spread through Asia and the 
Middle East, before reaching Central Europe at the end of the Neolithic (Hunt et al., 2008).

However, whereas in France wheat and barley were cultivated since the Neolithic (Ruas and Marinval, 1991; Martin et al., 2007), it is only during the Protohistoric times that cereal species became more diversified, and the first evidence from carpology of $P$. miliaceum culture can be dated back from the Early Bronze Age (ca. 1700 BC; Marinval, 1992, 1995). The Bronze and Iron Ages are clearly associated with intensified cultivation of this cereal in France. Millet grains were stored with their protecting envelopes (husks) for better preservation within the buried silos -like those found at Obernai - or in vases (Marinval, 1995). Following the conquest of Gaul, the Romans imported new varieties of cereals, mainly from the Mediterranean Basin, resulting in enhanced diversification of foodstuffs (Cabanis et al., 2015). This resulted in the progressive replacement of millet by other cereal species (e.g. rye), millet having been completely abandoned at the beginning of the Middle Age (Jacob et al,, 2008a). Notwithstanding this, cultivation of millet lasted in Obernai at least until the end of the $2^{\text {nd }}$ centuary $\mathrm{AD}$ - beginning of the $3^{\text {rd }}$ centuary AD.

\section{Conclusions}

The archaeological site of Obernai (NE France) has provided the opportunity to investigate past local agricultural practices following unearthing of a series of protohistoric silos from the Bronze and Iron Ages. GC-MS analysis of the lipids preserved in the soils filling the silos has shown the presence of miliacin, a triterpenoid methyl ether strictly associated with the cereal $P$. miliaceum (broomcorn millet). However, the $n$-alkyl lipid assemblage co-detected with miliacin was associated to C3-plant sources for which no specific lipids were identified. The absence of a $\mathrm{C} 4$ isotopic signature for the $n$-alkyl lipids was probably caused by the turnover of the SOM induced by a change of vegetation cover. Radiocarbon dating of miliacin, SOM and lipid extracts indicated that millet cropping was established during the Bronze Age and during the Roman Gaul period. The study represents the first evidence of millet cultivation in Alsace 
dating back to the Bronze Age, bringing a new perspective regarding agricultural practices and past diet in the East of France.

This study has also highlighted the potential of hollow archaeological structures like pits and silos to constitute "pedological traps" able to trap and archive soils surrounding the archaeological structures during their period of use or after abandoning. These filling soils have kept the molecular signatures from the various types of vegetation cover which developed on the surface soil horizons prior to being trapped in the structures, thereby potentially providing information about the past environment of archaeological sites in terms of vegetation cover or agricultural practices. This is notably the case for miliacin found in silos from the Iron Age in Obernai, attesting to millet cropping during the Bronze Age. The dating of lipids related to a given biological source and of specific biomarkers, together with their stable carbon isotopic composition, appeared to be critical for relating the molecular signatures to a specific chronological/historical context.

\section{Acknowledgements}

The INRAP (Institut National de Recherches Archéologiques Préventives) is thanked for providing the soil samples from the archaeological structures from Obernai, as is J. Jacob (Institut des Sciences de la Terre, Université d'Orléans, France) for providing an authentic miliacin standard and fresh material from broomcorn millet, and I. Antheaume and V. Grossi (University Claude Bernard Lyon I) for the bulk $\delta^{13} \mathrm{C}$ analysis of SOM. B.C. thanks the French Ministère de l'Enseignement Supérieur et de la Recherche for a doctoral fellowship. Part of the radiocarbon data was financed through the project IDEX 2015 ARCHEOSOL (University of Strasbourg). L. Wacker is thanked for support via GIS AMS analysis at ETH Zurich.

\section{References}


543 Balesdent, J., Wagner, G.H., Mariotti, A., 1988. Soil organic matter turnover in long-term field 544 experiments as revealed by carbon-13 natural abundance. Soil Science Society of America 545 Journal 52, 118-124.

546 Ballentine, D.C., Macko, S.A., Turekian, V.C., 1998. Variability of stable carbon isotopic 547 compositions in individual fatty acids from combustion of $\mathrm{C}_{4}$ and $\mathrm{C}_{3}$ plants: implications for 548 biomass burning. Chemical Geology 152, 151-161.

549 Bataille, G., 2014. Eckbolsheim, Bas-Rhin. Parc d'activité - Les fouilles archéologiques 550 préalables à la construction des parkings et zones annexes du Zénith. Report, Vol. 2, INRAP 551 Grand Est Sud, Strasbourg.

552 Bi, X., Sheng, G., Liu, X., Li, C., Fu, J., 2005. Molecular and carbon and hydrogen isotopic 553 composition of $n$-alkanes in plant leaf waxes. Organic Geochemistry 36, 1405-1417.

554 Birkholz, A., Smittenberg, R.H., Hajdas, I., Wacker, L., Bernasconi, S.M., 2013. Isolation and 555 compound specific radiocarbon dating of terrigenous branched glycerol dialkyl glycerol 556 tetraethers (brGDGTs). Organic Geochemistry 60, 9-19.

557 Boëda, E., Connan, J., Dessort, D., Muhesen, S., Mercier, N., Valladas, H., Tisnérat, N., 1996.

558 Bitumen as a hafting material on Middle Palaeolithic artefacts. Nature 380, 336-338.

559 Bossard, N., Jacob, J., Le Milbeau, C., Sauze, J., Terwilliger, V., Poissonnier, B., Vergès, E., 560 2013. Distribution of miliacin (olean-18-en-3 $\beta$-ol methyl ether) and related compounds in 561 broomcorn millet (Panicum miliaceum) and other reputed sources: Implications for the use of 562 sedimentary miliacin as a tracer of millet. Organic Geochemistry 63, 48-55.

563 Buckley, S.A., Evershed, R.P., 2001. Organic chemistry of embalming agents in Pharaonic and 564 Graeco-Roman mummies. Nature 413, 837-841. 
565 Bull, I.D., Simpson, I.A., Dockrill, S.J., Evershed, R.P., 1999. Organic geochemical evidence 566 for the origin of ancient anthropogenic soil deposits at Tofts Ness, Sanday, Orkney. Organic 567 Geochemistry 30, 535-556.

568 Bull I.D., Betancourt P.P., Evershed R.P., 2001. An organic geochemical investigation of the 569 practice of manuring at a Minoan site on Pseira Island, Crete. Geoarchaeology 16, 223-242.

570 Cabanis, M., Deberge, Y., Bouby, L., Hajnalovà, M., Marinval, P., Mennessier-Jouannet, C., 571 Vermeulen, C., Vernet, G., 2015. Changes in crop cultivation during the last five centuries 572 before the Roman conquest: archaeobotanical investigation in the Clermont-Ferrand basin, 573 Massif Central, France. Archaeological and Anthropological Sciences, 1-16.

574 Charrié-Duhaut, A., Connan, J., Rouquette, N., Adam, P., Barbotin, C., de Rozières, M.-F., 575 Tchapla, A., Albrecht, P., 2007. The canopic jars of Rameses II: real use revealed by molecular 576 study of organic residues. Journal of Archaeological Science 34, 957-967.

577 Charters, S., Evershed, R.P., Blinkhorn, P.W., Denham, V., 1995. Evidence for the mixing of 578 fats and waxes in archaeological ceramics. Archaeometry 37, 113-127.

579 Chikaraishi, Y., Naraoka, H., Poulson, S.R., 2004. Hydrogen and carbon isotopic fractionations 580 of lipid biosynthesis among terrestrial $\left(\mathrm{C}_{3}, \mathrm{C}_{4}\right.$ and $\left.\mathrm{CAM}\right)$ and aquatic plants. Phytochemistry $581 \quad 65,1369-1381$.

582 Chikaraishi, Y., Naraoka, H., 2006. Carbon and hydrogen isotope variation of plant biomarkers 583 in a plant-soil system. Chemical Geology 231, 190-202.

584 Chikaraishi, Y., Naraoka, H., 2007. $\delta 13 \mathrm{C}$ and $\delta \mathrm{D}$ relationships among three $n$-alkyl compound 585 classes ( $n$-alkanoic acid, $n$-alkane and $n$-alkanol) of terrestrial higher plants. Organic 586 Geichemistry 38, 198-215. 
Christl, M., Vockenhuber, C., Kubik, P.W., Wacker, L., Lachner, J., Alfimov, V., Synal, H.A., 2013. The ETH Zurich AMS facilities: performance parameters and reference materials. Nuclear Instruments and Methods in Physics Research B 294, 29-38.

Collister, J.W., Rieley, G., Stern, B., Eglinton, G., Fry, B., 1994. Compound-specific $\delta^{13} \mathrm{C}$ analyses of leaf lipids from plants with differing carbon dioxide metabolisms. Organic Geochemistry 21, 619-627.

Condamin, J., Formenti, F., Metais, M.O., Michel, M., Blond, P., 1976. The application of gas chromatography to the tracing of oil in ancient amphorae. Archaeometry 18, 195-201.

Connan, J., 1999. Use and trade of bitumen in antiquity and prehistory: molecular archaeology reveals secrets of past civilizations. Philosophical Transactions of the Royal Society B: Biological Sciences 354, 33-50.

Courel, B., Schaeffer, P., Adam, P., Ertlen, D., Schwartz, D., Bernasconi, S.M., Hajdas, I., 2015. Analyse, isolement et datation au ${ }^{14} \mathrm{C}$ de lipides dans les sols. L'exemple des tétraéthers de diglycérol. In : Poulenard, J., Rossi, M. (Eds.), Sols et Matières Organiques: Mémoires et Héritages. EDYTEM. Université de Savoie, Le Bourget-du Lac, pp 57-68.

Egli, M., Gristina, L., Wiesenberg, G.L.B., Civantos, J.M.M., Rotolo, A., Novara A., Brandová, D., Raimondi, S., 2013. From pedologic indications to archaeological reconstruction: deciphering land use in the Islamic period in the Baida district (north-western Sicily). Journal of Archaeological Science 40, 2670-2685.

Eglinton, G., Logan, G.A., 1991. Molecular preservation. Philosophical Transactions of the Royal Society B: Biological Sciences 333, 315-328.

Ertlen, D., Féliu, C., Michler, M., Schneider-Schwien, N., Schneikert, F., Thomas, Y., Braguier, S., Minni, D., Veber, C., 2013. Les structures de type « fente » dans le Kochersberg (Alsace): 
un programme de recherche en cours de développement. Revue archéologique de l'Est,

611 Supplément 33, 213-227.

612 Ertlen, D., Schwartz, D., Brunet, D., Trendel, J.-M., Adam, P., Schaeffer, P., 2015. Qualitative

613 near infrared spectroscopy, a new tool to recognize past vegetation signature in soil organic 614 matter. Soil Biology \& Biochemistry 82, 127-134.

615 Evershed, R.P., Heron, C., Goad, L.J., 1991. Epicuticular wax components preserved in 616 potsherds as chemical indicators of leafy vegetables in ancient diets. Antiquity $65,540-544$.

617 Fuller, D.Q., 2007. Contrasting patterns in crop domestication and domestication rates: recent 618 archaeobotanical insights from the Old World. Annals of Botany 100, 903-924.

619 Gierga, M., Hajdas, I., van Raden, U.J., Gilli, A., Wacker, L., Sturm, M., Bernasconi, S.M., 620 Smittenberg, R.H., 2016. Long-stored soil carbon released by prehistoric land use: evidence 621 from compound-specific radiocarbon analysis on Soppensee lake sediments. Quaternary 622 Science Reviews 144, 123-131.

623 Goude, G., Balasescu, A., Réveillas, H., Thomas, Y., Lefranc, P., 2015. Diet variability and 624 stable isotope analyses: looking for variables within the Late Neolithic and Iron Age human 625 groups from Gougenheim site and surrounding areas (Alsace, France). International Journal of 626 Osteoarchaeology 25, 988-996.

627 Hengtrakul, P. Lorenz, K., Mathias, M., 1991. Alkylresorcinol homologs in cereal grains. 628 Journal of Food Composition and Analysis 4, 52-57.

629 Huang, Y., Bol, R., Harkness, D.D., Ineson, P., Eglinton, G., 1996. Post-glacial variations in 630 distributions, ${ }^{13} \mathrm{C}$ and ${ }^{14} \mathrm{C}$ contents of aliphatic hydrocarbons and bulk organic matter in three 631 types of British acid upland soils. Organic Geochemistry 24, 273-287. 
632

633

634

635

636

637

638

639

640

641

642

643

644

645

646

647

648

649

650

651

652

653

Hunt, H.V., Linden, M.V., Liu, X., Motuzaite-Matuzeviciute, G., Colledge, S., Jones, M.K., 2008. Millets across Eurasia: chronology and context of early records of the genera Panicum and Setaria from archaeological sites in the Old World. Vegetation History and Archaeobotany 17 (Suppl 1), S5-S18.

Ingalls, A.E., Pearson, A., 2005. Ten years of compound-specific radiocarbon analysis. Oceanography 18, 18-31.

Jacob, J., Disnar, J.-R., Boussafir, M., Albuquerque, A.L.S., Sifeddine, A., Turcq, B., 2005. Pentacyclic triterpene methyl ethers in recent lacustrine sediments (Lagoa do Caçó, Brazil). Organic Geochemistry 36, 449-461.

Jacob, J., Disnar, J.-R., Arnaud, F., Chapron, E., Debret, M., Lallier-Vergès, E., Desmet, M., Revel-Rolland, M., 2008a. Millet cultivation history in the French Alps as evidenced by a sedimentary molecule. Journal of Archaeological Science 35, 814-820.

Jacob, J., Disnar, J.-R., Bardoux, G., 2008b. Carbon isotope evidence for sedimentary miliacin as a tracer of Panicum miliaceum (broomcorn millet) in the sediments of Lake le Bourget (French Alps). Organic Geochemistry 39, 1077-1080.

Koch, P.L., Fogel, M.L., Tuross, N., 1994. Tracing the diets of fossil animals using stable isotopes. In: Lajtha, K., Michener, R.H. (Eds.), Stable Isotopes in Ecology and Environmental Science, $1^{\text {st }}$ Edition. Blackwell Scientific Publications, pp. 63-92.

Kögel-Knabner, I., 2002. The macromolecular organic composition of plant and microbial residues as inputs to soil organic matter. Soil Biology \& Biochemistry 34, 139-162.

Laporte, L., 2001. Guilaine, (J.), Dir. - Premiers paysans du monde, naissance des agricultures. Séminaire du Collège de France. Revue Archéologique de l'Ouest 18, 240-242. 
654 Lavrieux, M., Jacob, J., Le Milbeau, C., Zocatelli, R., Masuda, K., Bréheret, J.-G., Disnar, J.655 R., 2011. Occurrence of triterpenyl acetates in soil and their potential as chemotaxonomical 656 markers of Asteraceae. Organic Geochemistry 42, 1315-1323.

657 Lavrieux, M., Bréheret, J.-G., Disnar, J.-R., Jacob, J., Le Milbeau, C., Zocatelli, R., 2012. 658 Preservation of an ancient grassland biomarker signature in a forest soil from the French Massif 659 Central. Organic Geochemistry 51, 1-10.

Lavrieux, M., Jacob, J., Disnar, J.-R., Bréheret, J.-G., Le Milbeau, C., Miras, Y., Andrieu-Ponel, 661 V., 2013. Sedimentary cannabinol tracks the history of hemp retting. Geology 41, 751-754.

662 Lichtfouse, E., Dou, S., Houot, S., Barriuso, E., 1995. Isotope evidence for soil organic carbon 663 pools with distinct turnover rate -II. Humic substances. Organic Geochemistry 23, 845-847.

664 Lichtfouse, E., Bardoux, G., Mariotti, A., Balesdent, J., Ballentine, D.C., Macko, S.A., 1997. 665 Molecular, ${ }^{13} \mathrm{C}$, and ${ }^{14} \mathrm{C}$ evidence for the allochthonous and ancient origin of $\mathrm{C}_{16}-\mathrm{C}_{18} n$-alkanes 666 in modern soils. Geochimica et Cosmochimica Acta 61, 1891-1898.

667 Lorenz, K., Lal, R., Preston, C.M., Nierop, K.G.J., 2007. Strengthening the soil organic carbon 668 pool by increasing contributions from recalcitrant aliphatic bio(macro)molecules. Geoderma $669142,1-10$.

670 Lu, H., Zhang J., Liu, K.-B., Wu, N., Li, Y., Zhou, K., Ye, M., Zhang, T., Zhang, H., Yang, X., 671 Shen, L., Xu, D., Li, Q., 2009. Earliest domestication of common millet (Panicum miliaceum) 672 in East Asia extended to 10,000 years ago. Proceedings of the National Academy of Sciences 673 USA 106, 7367-7372.

674 Marinval, P., 1992. Archaeobotanical data on millets (Panicum miliaceum and Setaria italica) 675 in France. Review of Palaeobotany and Palynology 73, 259-270. 
Marinval, P., 1995. Données carpologiques françaises sur les Millets (Panicum miliaceum L. et

Setaria italica (L.) Beauv.) de la Protohistoire au Moyen Age. In: Hörandner, E. (Ed.), Millet: Actes du Congrès d'Aizenay, 18-19 août 1990. Peter Lang, Frankfurt, pp. 31-61.

Mariotti, A., Peterschmitt, E., 1994. Forest savanna ecotone dynamics in India as revealed by carbon isotope ratios of soil organic matter. Oecologia 97, 475-480.

Martin, L., Thiébault, S., Rey, P.-J., 2007. Production et consommation végétale durant la Préhistoire récente: études archéobotaniques de quelques sites des Alpes occidentales. In: Boëtsch, G., Hubert, A (Eds.), Alimentation et Montagne, Actes de la $6^{\text {ème }}$ Université Européenne d'Eté «Anthropologie des Populations Alpines », Gap, France. Editions des Hautes-Alpes, Gap, pp. 11-24.

Mendez-Millan, M., Nguyen Tu, T.T., Balesdent, J., Derenne, S., Derrien, D., Egasse, C., Thongo M'Bou, A., Zeller, B., Hatté, C., 2014. Compound-specific ${ }^{13} \mathrm{C}$ and ${ }^{14} \mathrm{C}$ measurements improve the understanding of soil organic matter dynamics. Biogeochemistry 118, 205-223.

Mollenhauer, G., Rethemeyer, J., 2009. Compound-specific radiocarbon analysis - analytical challenges and applications. IOP Conferences Series: Earth and Environmental Science 5, 012006.

Motuzaite-Matuzeviciute, G., Jacob, J., Telizhenko, S., Jones, M.K., 2016. Miliacin in palaeosols from an Early Iron Age in Ukraine reveals in situ cultivation of broomcorn millet. Archaeological and Anthropological Sciences 8, 43-50.

Ohmoto, T., Ikuse, M., Natori, S., 1970. Triterpenoids of the Gramineae. Phytochemistry 9, 2137-2148.

O’Leary, M.H., 1988. Carbon isotopes in photosynthesis. BioScience 38, 328-336. 
698

699

700

701

702

703

704

705

706

707

708

709

710

711

712

713

714

715

716

717

718

719

Pessenda, L.C.R., Gomes, B.M., Aravena, R., Ribeiro, A.S., Boulet, R., Gouveia, S.E.M., 1998.

The carbon isotope record in soils along a forest-cerrado ecosystem transect: implications for vegetation changes in the Rondonia state, southwestern Brazilian Amazon region. The Holocene 8, 599-603.

Quénéa, K., Largeau, C., Derenne, S., Spaccini, R., Bardoux, G., Mariotti, A., 2006. Molecular and isotopic study of lipids in particle size fractions of a sandy cultivated soil (Cestas cultivation sequence, southwest France): Sources, degradation, and comparison with Cestas forest soil. Organic Geochemistry 37, 20-44.

Reddé, M., Nuber, H.U., Jacomet, S., Schibler, J., Schucany, C., Schwarz, P.-A., Seitz, G., Ginella, F., Joly, M., Plouin, S., Hüster Plogmann, H., Petit, C., Popovitch, L., Schlumbaum, A., Vandorpe, P., Viroulet, B., Wick, L., Wolf, J.-J., Gissinger, B., Ollive, V., Pellissier, J., 2005. Oedenburg. Une agglomération d'époque romaine sur le Rhin supérieur: fouilles françaises, allemandes et suisses à Biesheim-Kunheim (Haut-Rhin). Gallia 62, 215-277.

Reimer, P.J., Bard, E., Bayliss, A., Beck, J.W., Blackwell, P.G., Ramsey, C.B., Buck, C.E., Cheng, H., Edwards, R.L., Friedrich, M., Grootes, P.M., Guilderson, T.P., Haflidason, H., Hajdas, I., Hatté, C., Heaton, T.J., Hoffmann, D.L., Hogg, A.G., Hughen, K.A., Kaiser, K.F., Kromer, B., Manning, S.W., Niu, M., Reimer, R.W., Richards, D.A., Scott, E.M., Southon, J.R., Staff, R.A., Turney, C.S.M., van der Plicht, J., 2013. IntCal13 and Marine13 radiocarbon age calibration curves 0-50,000 years cal BP. Radiocarbon 55, 1869-1887.

Rethemeyer, J., Kramer, C., Gleixner, G., Wiesenberg, G.L.B., Schwark, L., Andersen, N., Nadeau, M.-J., Grootes, P.M., 2004. Complexity of soil organic matter: AMS ${ }^{14} \mathrm{C}$ analysis of soil lipid fractions and individual compounds. Radiocarbon 46, 465-473. 
Rethemeyer, J., Kramer, C., Gleixner, G., John, B., Yamashita, T., Flessa, H., Andersen, N., Nadeau, M.-J., Grootes, P.M., 2005. Transformation of organic matter in agricultural soils: radiocarbon concentration versus soil depth. Geoderma 128, 94-105.

Rieley, G., 1994. Derivatization of organic compounds prior to gas chromatographiccombustion-isotope ratio mass spectrometric analysis: identification of isotope fractionation processes. Analyst 119, 915-919.

Ross, A.B., Shepherd, M.J., Schüpphaus, M., Sinclair, V., Alfaro, B., Kamal-Eldin, A., Åman, P., 2003. Alkylresorcinols in cereal and cereal products. Journal of Agricultural and Food Chemistry 51, 4111-4118.

Ross, A.B., Åman, P., Andersson, R., Kamal-Eldin, A., 2004. Chromatographic analysis of alkylresorcinols and their metabolites. Journal of Chromatography A 1054, 157-164.

Ruas, M.-P., Marinval, P., 1991. Alimentation végétale et agriculture d'après les semences archéologiques (de 9000 av. J.-C. au XV e siècle). In: Guilaine, J. (Ed), Pour une Archéologie Agraire. Armand Colin, pp. 409-439.

Ruff, M., Wacker, L., Gäggeler, H.W., Suter, M., Synal, H.-A., Szidat, S., 2007. A gas ion source for radiocarbon measurements at $200 \mathrm{kV}$. Radiocarbon 49, 307-314.

Ruff, M., Fahrni, S., Gäggeler, H.W., Hajdas, I., Suter, M., Synal, H.-A., Szidat, S., Wacker, L., 2010. On-line radiocarbon measurements of small samples using elemental analyzer and MICADAS gas ion source. Radiocarbon 52, 1645-1656.

Schmidt, M.W.I., Torn, M.S., Abiven, S., Dittmar, T., Guggenberger, G., Janssens, I.A., Kleber, M., Kögel-Knabner, I., Lehmann, J., Manning, D.A.C., Nannipieri, P., Rasse, D.P., Weiner, S., Trumbore, S.E., 2011. Persistence of soil organic matter as an ecosystem property. Nature 478, 49-56. 
743 Schnell, G., Schaeffer, P., Tardivon, H., Motsch, E., Connan, J., Ertlen, D., Schwartz, D., 744 Schneider, N., Adam, P., 2014. Contrasting diagenetic pathways of higher plant triterpenoids 745 in buried wood as a function of tree species. Organic Geochemistry 66, 107-124.

746 Schwartz, D., 1991. Intérêt de la mesure du $\delta^{13} \mathrm{C}$ des sols en milieu naturel équatorial pour la 747 connaissance des aspects pédologiques et écologiques des relations savane-forêt. Cahiers 748 ORSTOM, Série Pédologie 26, 327-341.

749 Schwartz, D., 2012. Les temps du sol : interprétations temporelles de l'archivage pédologique 750 dans les approches paléoenvironnementalistes et géoarchéologiques. Étude \& Gestion des Sols $751 \quad 19,51-65$.

752 Seitz, L.M., 1992. Identification of 5-(2-oxoalkyl)resorcinols and 5-(2-oxoalkenyl)resorcinols 753 in wheat and rye grains. Journal of Agricultural and Food Chemistry 40, 1541-1546.

754 Sistiaga, A., Mallol C., Galván, B., Summons, R.E., 2014. The Neanderthal meal: a new 755 perspective using faecal biomarkers. PLOS ONE 9, e101045.

756 Stuiver, M., Polach, H.A., 1977. Discussion: reporting of ${ }^{14} \mathrm{C}$ data. Radiocarbon 19, 355-363.

757 Synal, H.-A., Stocker, M., Suter, M., 2007. MICADAS: a new compact radiocarbon AMS 758 system. Nuclear Instruments and Methods in Physics Research B 259, 7-13.

759 Trendel, J.M., Schaeffer, P., Adam, P., Ertlen, D., Schwartz, D., 2010. Molecular 760 characterisation of soil surface horizons with different vegetation in the Vosges Massif (France).

761 Organic Geochemistry 41, 1036-1039.

762 Tulloch, A.P., 1982. Epicuticular waxes of Panicum miliaceum, Panicum texanum and Setaria 763 italica. Phytochemistry 21, 2251-2255. 
764

765

766

767

768

van Bergen, P.F., Bull, I.D., Poulton, P.R., Evershed, R.P., 1997. Organic geochemical studies of soils from the Rothamsted classical experiments - I. Total lipid extracts, solvent insoluble residues and humic acids from Broadbalk Wilderness. Organic Geochemistry 26, 117-135.

van der Merwe, N.J., Vogel, J.C., 1983. Recent carbon isotope research and its implications for African archaeology. African Archaeological Review 1, 35-56.

Vandorpe, P., Jacomet, S., 2011. Plant economy and environment. In: Vandorpe, P., Plant macro remains from the $1^{\text {st }}$ and $2^{\text {nd }}$ Cent. A.D. in Roman Oedenburg/Biesheim-Kunheim (F). Methodological aspects and insights into local nutrition, agricultural practices, import and the natural environment. Habilitation Thesis, University of Basel, Switzerland.

Vandorpe, P., Wick, L., 2015. Food plants in anthropogenic sediments as represented in pollen and macrofossil spectra: a case study on waterlogged Roman sediments from Switzerland and Alsace, France. Vegetation History and Archaeobotany 24, 135-142.

Wacker, L., Němec, M., Bourquin, J., 2010a. A revolutionary graphitisation system: fully automated, compact and simple. Nuclear Instruments and Methods in Physics Research B 268, 931-934.

Wacker, L., Bonani, G., Friedrich, M., Hajdas, I., Němec, M., Ruff, M., Suter, M., Synal, H.A., Vockenhuber, C., 2010b. MICADAS: routine and high-precision radiocarbon dating. Radiocarbon 52, 252-262.

Wang, J., Liu, L., Ball, T., Yu, L., Li, Y., Xing, F., 2016. Revealing a 5,000-y-old beer recipe in China. Proceedings of the National Academy of Sciences USA 113, 6444-6448.

Wiesenberg, G.L.B., Schwarzbauer, J., Schmidt, M.W.I., Schwark, L., 2004. Source and turnover of organic matter in agricultural soils derived from $n$-alkane/n-carboxylic acid compositions and C-isotope signatures. Organic Geochemistry 35, 1371-1393. 
787 Wiethold, J., 2000. Macro-restes végétaux imbibés et carbonisés du premier âge du Fer 788 provenant de fouille sauvetage de chantier 'les résidences du vignoble' à Hattstatt789 'Ziegelscheuer' (Haut-Rhin). In: Dumont, A., Treffort, J.M. (Eds), Hattstatt «Ziegelsheuer» 790 «Les résidences du vignoble », 68 - Haut-Rhin, Puits à eau protohistoriques (Bronze Ancien 791 et Hattstatt C). Afan Grand-Est, Strasbourg.

792 Winata, A., Lorenz, K., 1997. Effects of fermentation and baking of whole wheat and whole 793 rye sourdough breads on cereal alkylresorcinols. Cereal Chemistry 74, 284-287. 
796 Fig. 1. Photos and cross-sections of selected archaeological structures unearthed at Obernai 797 (Alsace, NE France); a, Silo 1330; b, Gaulish pit; c, Roman Gaul latrines; AL, Archaeological 798 layer; LS, loess substrate. Photos and drawings by Clément Féliu (INRAP).

799 Fig. 2. Gas chromatograms (GC-MS, conditions B) of the apolar fraction from the lipid extract 800 from (a) silo 1330.AL2, (b) silo 1330.LS, (c) pit 1001.AL23 and (d) latrines 4564.AL8 (Obernai, 801 NE France). Carboxylic acids are analysed as methyl esters and alcohols as acetates. Numbers 802 refer to structures in Appendix A.

803 Fig. 3. Amount of miliacin ( $\mu \mathrm{g} / \mathrm{g}$ soil) in the soils collected within the archaeological layers of 804 the silos (AL) and the Gaulish pit as well as in their respective loess substrates (LS).

805 Fig. 4. Graphical representation of ${ }^{14} \mathrm{C}$ age cal. BP obtained for isolated miliacin samples (in 806 blue), lipid extracts (in red), soil organic matter (in grey), carbonized grains of millet (in green) 807 in respect to the age of the archaeological structures determined by ceramology. The non808 calibrated ${ }^{14} \mathrm{C}$ ages are marked with a black cross (for standard deviation, see Table 3 ). 


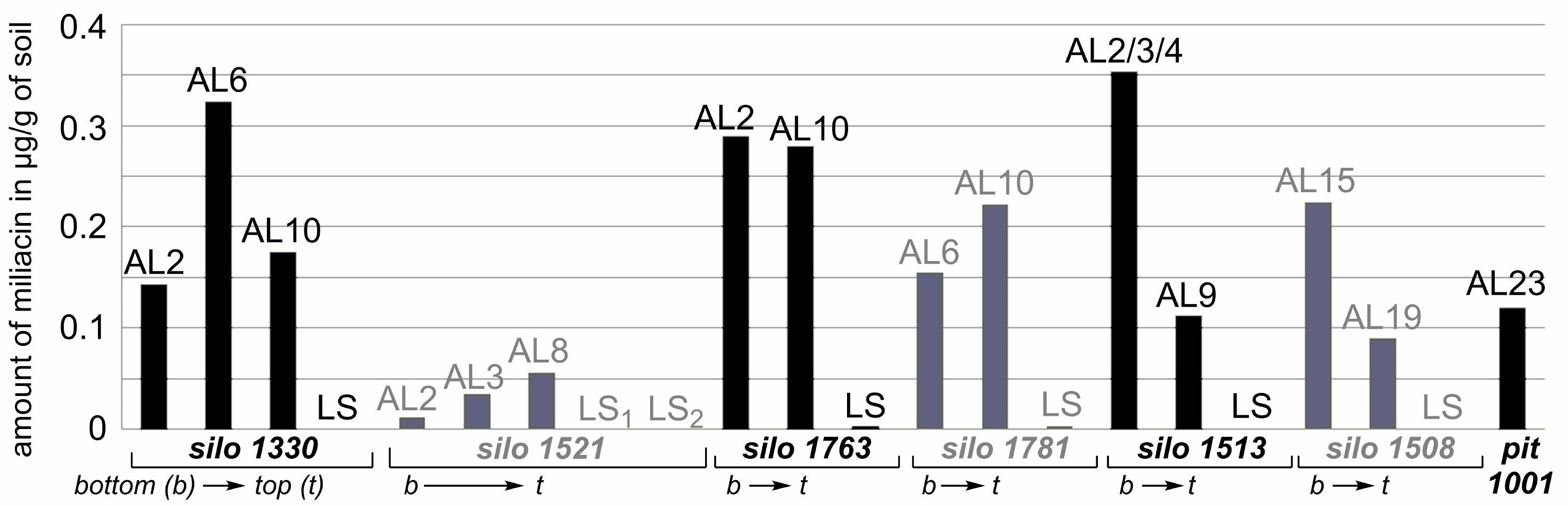




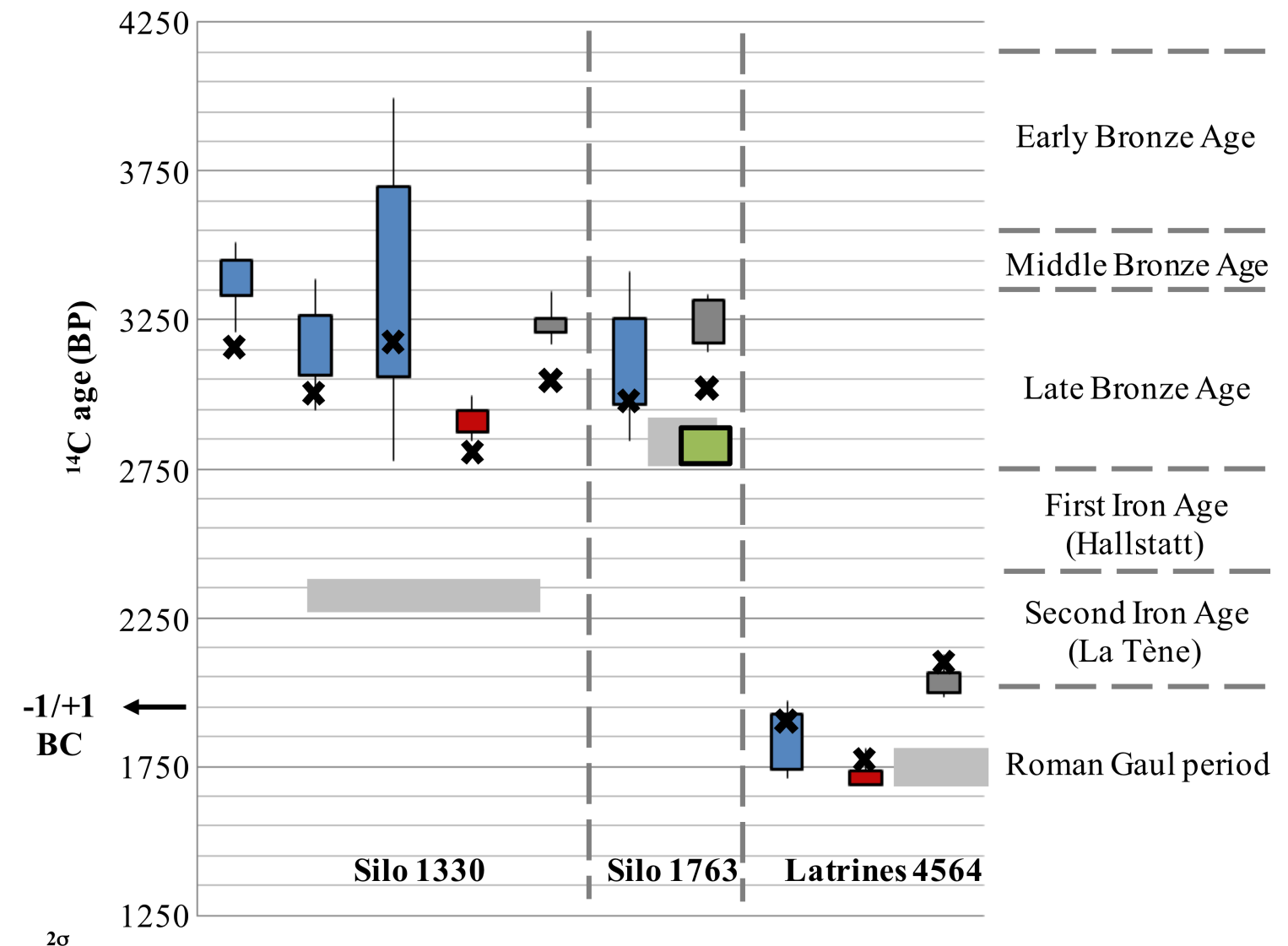

10 — miliacin (cal. BP) $\square$ grains of P. miliaceum (cal. BP) $\square \operatorname{SOM}($ cal. BP)

lipid extract (cal. BP)

dating by ceramology (BP) $\mathbf{X}$ Respective ${ }^{14} \mathrm{C}$ age BP (non-calibrated) 
Table 1

Archaeological structures sampled for lipid analysis and age of the structures determined from ceramology.

\begin{tabular}{cccc}
\hline & Archaeological age & Historical period & Sampling level $^{\text {a }}$ \\
$\mathbf{1 3 3 0}$ & $400-260 \mathrm{BC}$ & Silos & \\
$\mathbf{1 5 0 8}$ & $400-260 \mathrm{BC}$ & La Tène B & AL2, AL6, AL10, LS \\
$\mathbf{1 5 1 3}$ & $400-260 \mathrm{BC}$ & La Tène B & AL15, AL19, LS \\
$\mathbf{1 5 2 1}$ & $150-30 \mathrm{BC}$ & La Tène B & AL2/3/4, AL9, LS \\
$\mathbf{1 7 6 3}$ & $950-800 \mathrm{BC}$ & La Tène D & AL2, AL3, AL8, LS1, LS2 \\
$\mathbf{1 7 8 1}$ & $400-260 \mathrm{BC}$ & Late Bronze Age & AL2, AL10, LS \\
$\mathbf{1 8 1 7}$ & $4600-4300 \mathrm{BC}$ & La Tène B & AL6, AL10, LS \\
& & Neolithic period & AL3, AL8, AL9, LS1, LS2 \\
$\mathbf{4 5 6 4}$ & End of $2^{\text {nd }}$ c. AD - & Latrines & AL4, AL8, AL9, LS \\
& beginning of the $3^{\text {rd }}$ c. AD & Roman period & \\
\hline $\mathbf{1 0 0 1}$ & $150-30 \mathrm{BC}$ & Gaulish pit & AL23, LS \\
\hline
\end{tabular}

${ }^{a}$ Location within the archaeological layers (AL) of the structures and in the loess substrates (LS) are illustrated in Fig. 1 and Fig. S1 (Supplementary data). 
Table 2

Stable carbon isotopic composition $\left(\delta^{13} \mathrm{C}, \%\right.$ vs. VPDB) and standard deviation $( \pm \sigma)$ of individual lipids from selected silo samples $(\mathrm{AL})$ and one loess substrate sample (LS ; n.d., not determined).

\begin{tabular}{|c|c|c|c|c|c|c|c|c|c|c|c|c|}
\hline$\delta^{13} \mathrm{C}$ & 1330.AL2 & 1508.AL15 & 1508.LS & 1513.AL9 & 1521.AL8 & 1817.AL3 & 1763.AL2 & $\delta^{13} \mathrm{C}$ & 1508.AL15 & 1513.AL9 & 1521.AL8 & 1763.AL2 \\
\hline \multicolumn{8}{|c|}{$n$-Alkanes } & \multicolumn{5}{|c|}{$n$-Acids ${ }^{\mathrm{a}}$} \\
\hline $\mathrm{C}_{25}$ & $-31.8( \pm 0.7)$ & $-32.1( \pm 0.5)$ & $-33.1( \pm 0.4)$ & $-32.5( \pm 0.2)$ & $-31.8( \pm 0.4)$ & $-31.8( \pm 0.5)$ & $-29.9( \pm 0.5)$ & $\mathrm{C}_{20}$ & $-32.6( \pm 0.4)$ & n.d. & n.d. & $-31.6( \pm 0.2)$ \\
\hline $\mathrm{C}_{27}$ & $-31.5( \pm 0.6)$ & $-31.9( \pm 0.2)$ & $-32.1( \pm 0.3)$ & $-31.9( \pm 0.2)$ & $-31.7( \pm 0.4)$ & $-32.5( \pm 0.1)$ & $-30.4( \pm 0.2)$ & $\mathrm{C}_{22}$ & $-33.8( \pm 0.2)$ & n.d. & n.d. & $-31.7( \pm 0.2)$ \\
\hline $\mathrm{C}_{29}$ & $-33.5( \pm 0.5)$ & $-34.0( \pm 0.3)$ & $-33.6( \pm 0.1)$ & $-33.9( \pm 0.1)$ & $-33.5( \pm 0.3)$ & $-33.5( \pm 0.2)$ & $-32.5( \pm 0.2)$ & $\mathrm{C}_{24}$ & $-32.8( \pm 0.2)$ & n.d. & n.d. & $-32.8( \pm 0.3)$ \\
\hline $\mathrm{C}_{31}$ & $-34.7( \pm 0.2)$ & $-34.5( \pm 0.2)$ & $-34.2( \pm 0.1)$ & $-35.4( \pm 0.5)$ & $-34.1( \pm 0.5)$ & $-34.3( \pm 0.2)$ & $-33.4( \pm 0.2)$ & $\mathrm{C}_{26}$ & $-33.7( \pm 0.4)$ & n.d. & n.d. & $-34.7( \pm 0.4)$ \\
\hline $\mathrm{C}_{33}$ & $-35.5( \pm 0.3)$ & $-33.0( \pm 0.1)$ & $-33.5( \pm 0.3)$ & $-33.9( \pm 0.2)$ & $-34.5( \pm 1.0)$ & $-34.5( \pm 0.3)$ & $-32.9( \pm 0.4)$ & $\mathrm{C}_{28}$ & $-34.6( \pm 0.2)$ & n.d. & n.d. & $-36.3( \pm 0.4)$ \\
\hline \multicolumn{8}{|c|}{$n$-Alcohols ${ }^{\mathrm{a}}$} & $\mathrm{C}_{30}$ & n.d. & n.d. & n.d. & $-36.2( \pm 0.4)$ \\
\hline $\mathrm{C}_{22}$ & $-33.6( \pm 0.6)$ & $-33.8( \pm 0.4)$ & $-33.6( \pm 0.3)$ & $-32.6( \pm 0.2)$ & $-33.6( \pm 0.4)$ & $-33.8( \pm 0.4)$ & $-33.4( \pm 0.3)$ & $\mathrm{C}_{32}$ & $-34.9( \pm 0.7)$ & n.d. & n.d. & $-37.0( \pm 0.5)$ \\
\hline $\mathrm{C}_{24}$ & $-33.6( \pm 0.3)$ & $-33.9( \pm 0.1)$ & $-34.3( \pm 0.2)$ & $-33.7( \pm 0.4)$ & $-32.8( \pm 0.1)$ & $-33.4( \pm 0.4)$ & $-34.8( \pm 0.2)$ & \multicolumn{5}{|c|}{ Miliacin (12) } \\
\hline $\mathrm{C}_{26}$ & $-35.9( \pm 0.2)$ & $-36.2( \pm 0.1)$ & $-35.4( \pm 0.1)$ & $-36.2( \pm 0.2)$ & $-36.1( \pm 0.2)$ & $-34.9( \pm 0.2)$ & $-36.8( \pm 0.2)$ & & $-21.6( \pm 0.1)$ & $-21.5( \pm 0.1)$ & $-21.3( \pm 0.3)$ & n.d. \\
\hline $\mathrm{C}_{28}$ & $-36.2( \pm 0.2)$ & $-36.1( \pm 0.1)$ & $-35.6( \pm 0.1)$ & $-36.1( \pm 0.2)$ & $-35.8( \pm 0.2)$ & $-35.3( \pm 0.6)$ & $-35.5( \pm 0.1)$ & & & & & \\
\hline $\mathrm{C}_{30}$ & $-34.6( \pm 0.5)$ & $-34.9( \pm 0.2)$ & $-35.6( \pm 0.5)$ & $-35.1( \pm 0.3)$ & $-35.8( \pm 0.2)$ & $-35.3( \pm 0.3)$ & n.d. & & & & & \\
\hline $\mathrm{C}_{32}$ & $-33.6( \pm 0.7)$ & $-31.4( \pm 0.2)$ & $-32.6( \pm 0.4)$ & $-33.1( \pm 0.4)$ & $-32.7( \pm 0.1)$ & $-35.4( \pm 0.2)$ & $-33.2( \pm 0.4)$ & & & & & \\
\hline
\end{tabular}

${ }^{a}$ Values corrected for derivatization agent $\left[\mathrm{Si}\left(\mathrm{CH}_{3}\right)_{3}\right.$ and $\mathrm{CH}_{3}$ for the $n$-alcohols and $n$-acids, respectively]. 
Table 3

${ }^{14} \mathrm{C}$ age (in $\mathrm{BP}^{\mathrm{a}}$ and cal. $\mathrm{BC} / \mathrm{AD}^{\mathrm{b}}$ ) of soil organic matter (SOM), lipid extract (LE) and isolated miliacin (12) from selected soil samples.

\begin{tabular}{|c|c|c|c|c|}
\hline Sample & Amount of soil & $\begin{array}{l}\text { SOM (decarbonated soil) } \\
\operatorname{Age}^{14} \mathrm{CBP}^{\mathrm{a}}( \pm 1 \sigma)\end{array}$ & Cal. age ${ }^{14} \mathrm{C}(68 \%)^{\mathrm{b}}$ & Cal. age ${ }^{14} \mathrm{C}(95 \%)^{\mathrm{b}}$ \\
\hline 1330.AL6 ${ }^{\mathrm{c}}$ & $230 \mathrm{mg}$ & $3042( \pm 28)$ & $\begin{array}{l}1381-1343 \mathrm{BC}^{\mathrm{e}}(27 \%) \\
1307-1260 \mathrm{BC}(38 \%)\end{array}$ & $1396-1218$ BC (95\%) \\
\hline $1330 . \mathrm{LS}^{\mathrm{d}}$ & $140 \mathrm{mg}$ & $7597( \pm 54)$ & $6492-6412$ BC (68\%) & $6589-6378$ BC (95\%) \\
\hline 1763.AL2 ${ }^{\mathrm{c}}$ & $200 \mathrm{mg}$ & $3022( \pm 23)$ & $1366-1221$ BC (68\%) & $1386-1195$ ВC (95\%) \\
\hline 4564.AL $8^{d}$ & $145 \mathrm{mg}$ & $2072( \pm 27)$ & $\begin{array}{l}154-136 \mathrm{BC}(11 \%) \\
114-46 \mathrm{BC}(57 \%)\end{array}$ & $175-36 \mathrm{BC}(92 \%)$ \\
\hline Sample & Amount of LE & $\begin{array}{c}\text { LE } \\
\operatorname{Age}{ }^{14} \mathrm{C} \mathrm{BP}( \pm 1 \sigma)\end{array}$ & Cal. age ${ }^{14} \mathrm{C}(68 \%)$ & Cal. age ${ }^{14} \mathrm{C}(95 \%)$ \\
\hline 1330.AL6 & $1.3 \mathrm{mg}$ & $2806( \pm 28)$ & 996-922 BC (68\%) & $1044-896$ BC (95\%) \\
\hline 1330.LS & $0.8 \mathrm{mg}$ & $122( \pm 27)$ & $\begin{array}{l}1685-1707 \mathrm{AD}^{\mathrm{f}}(12 \%) \\
1833-1885 \mathrm{AD}(31 \%)\end{array}$ & $\begin{array}{l}1679-1764 \mathrm{AD}(33 \%) \\
1801-1897 \mathrm{AD}(48 \%) \\
1902-1940 \mathrm{AD}(15 \%)\end{array}$ \\
\hline 4564.AL8 & $1.5 \mathrm{mg}$ & $1784( \pm 25)$ & $\begin{array}{l}215-260 \mathrm{AD}(38 \%) \\
280-325 \mathrm{AD}(30 \%)\end{array}$ & $\begin{array}{l}138-264 \mathrm{AD}(61 \%) \\
274-330 \mathrm{AD}(34 \%)\end{array}$ \\
\hline Sample & Amount of $\mathbf{1 2}$ & $\begin{array}{c}\text { Miliacin (12) } \\
\text { Age }{ }^{14} \mathrm{C} \mathrm{BP}( \pm 1 \sigma)\end{array}$ & Cal. age ${ }^{14} \mathrm{C}(68 \%)$ & Cal. age ${ }^{14} \mathrm{C}(95 \%)$ \\
\hline 1330.AL2 & $40 \mu \mathrm{g}$ & $3151( \pm 66)$ & $1501-1381$ BC (55\%) & $1560-1259$ BC (93\%) \\
\hline 1330.AL6 & $27 \mu \mathrm{g}$ & $2999( \pm 87)$ & $1317-1116$ BC (57\%) & $1438-996$ BC (95\%) \\
\hline 1330.AL10 & $38 \mu \mathrm{g}$ & $3175( \pm 255)$ & $1750-1110 \mathrm{BC}(68 \%)$ & $2044-826$ BC (95\%) \\
\hline 1763.AL2 & $15 \mu \mathrm{g}$ & $2967( \pm 127)$ & $1307-1015$ BC (61\%) & $1461-894$ BC (93\%) \\
\hline 4564.AL8 & $300 \mu \mathrm{g}$ & $1906( \pm 50)$ & $26-209 \mathrm{AD}(68 \%)$ & $19 \mathrm{BC}-236 \mathrm{AD}(95 \%)$ \\
\hline
\end{tabular}

${ }^{a}$ BP: "Before Present" where the year 1950 , when nuclear weapons testing changed the ${ }^{14} \mathrm{C}$ concentration in the atmosphere, is the reference $(0 \mathrm{BP})$; ${ }^{b}$ the radiocarbon content within the atmosphere having varied over time, the calibration atmospheric curve used for the study includes important fluctuations (IntCal13; Reimer et al., 2013). the highest the highest statistical probability are reported here and used in Fig. 4, whereas the complete ${ }^{14} \mathrm{C}$ dating data are reported in Table $\mathrm{S} 3$ (Supplementary material); ${ }^{\circ}$ measure performed on soil sanple aftr solvent extraction and decabonation, "measure achieved on decarbonated soil sample, "BC. Before Christ; ${ }^{\circ} \mathrm{A},$. . Anno Domini; ${ }^{\mathrm{g}}$ sample likely contaminated by input from recent organic material. 


\section{Highlights}

-Miliacin (millet biomarker) found in paleosoils filling archaeological structures. $\bullet$ It was ${ }^{14} \mathrm{C}$-dated after chromatographic isolation. $\bullet$ Hence, millet cropping was dated back to the Bronze Age. $\cdot$ Hollow structures act as "pedological traps" by sealing ancient cultivated soils. $\cdot$ The $\delta^{13} \mathrm{C}$ lipid signature was used to decipher the $\mathrm{C}_{3}$ vs. $\mathrm{C}_{4}$ plant input to SOM. 


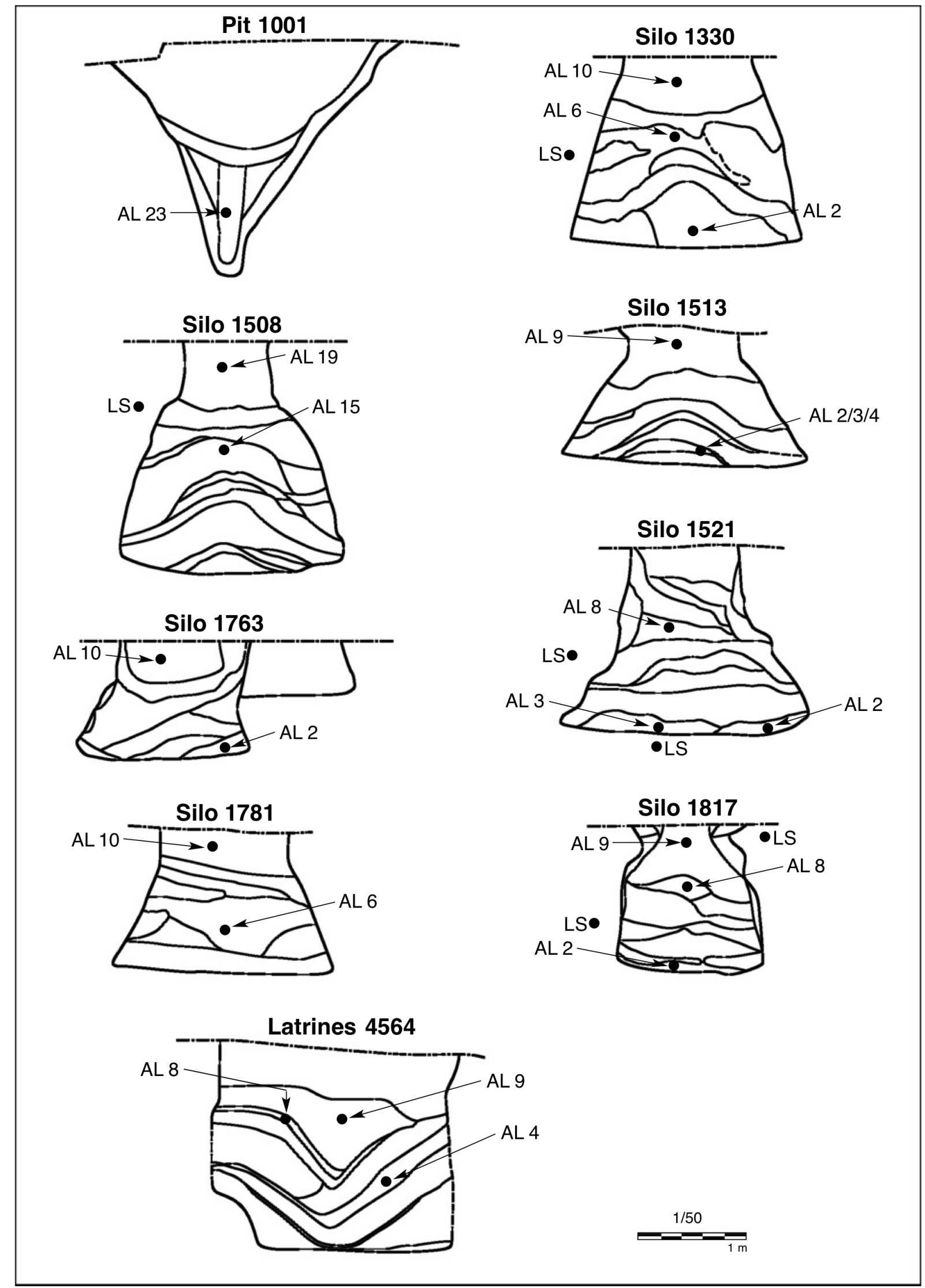

Fig. S1. Archaeological structures and location of samples in the archaeological layers (AL) and loess substrates (LS). Drawing modified after Clément Féliu (INRAP). 


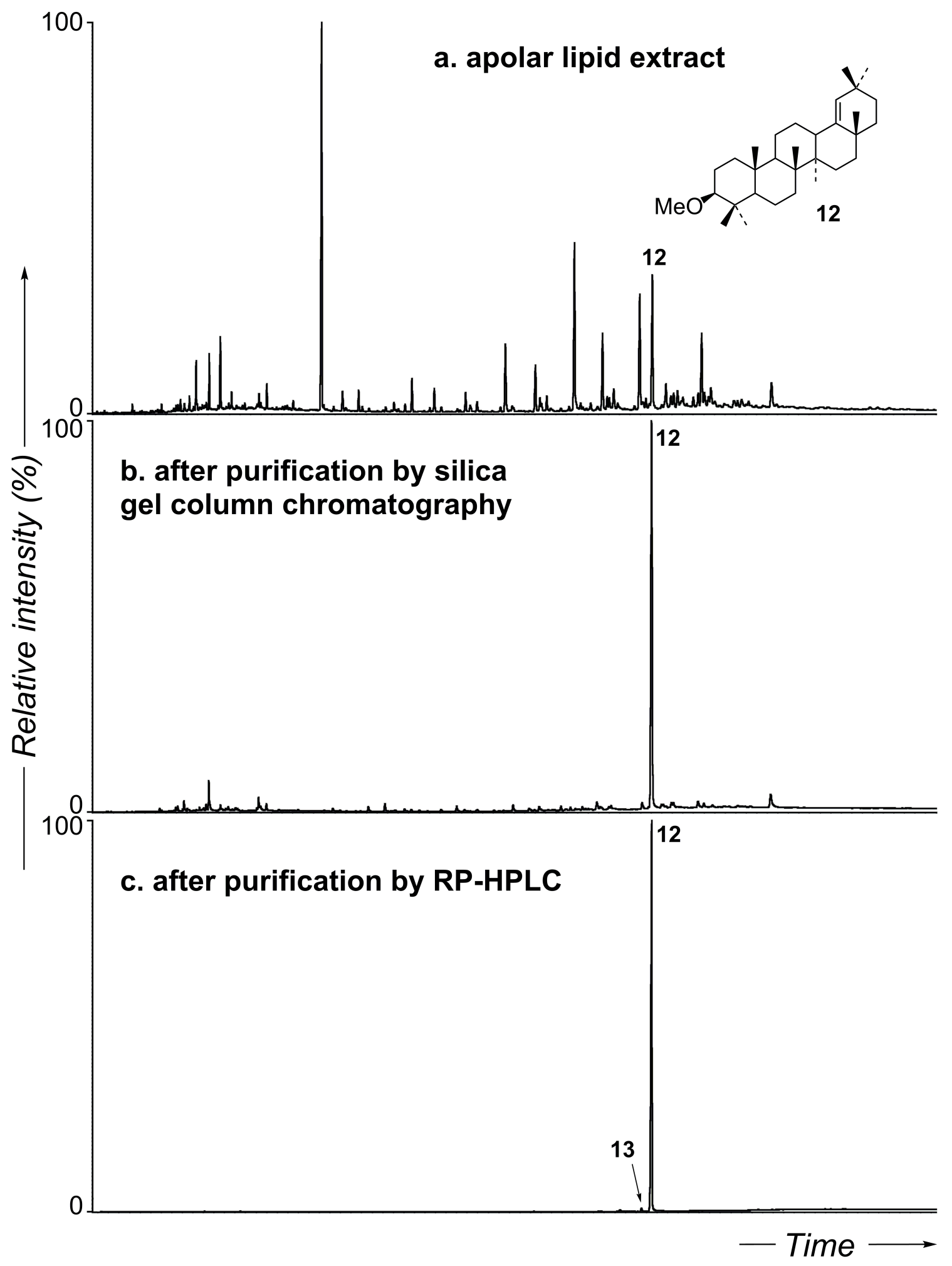

Fig. S2. Gas chromatograms (GC-MS) showing (a) apolar lipid extract from silo 1330.AL2, (b) miliacin-enriched fraction after a separation step using silica gel column chromatography (fraction eluted with $\mathrm{CH}_{2} \mathrm{Cl}_{2}$; cf. Section 2.6) and (c) isolated miliacin (12) after last purification step with RP-HPLC. 


\section{Table S1}

MS data (EI, $70 \mathrm{eV}$ ) of sterols and triterpenoids in lipid extracts from the archaeological soil samples.

\begin{tabular}{|c|c|c|c|}
\hline Compound & $\mathrm{MW}^{\mathrm{a}}$ & Main MS fragments $(\mathrm{m} / \mathrm{z})$ & Reference(s) \\
\hline Stigmasterol (Ac) 1 & 454 & 147 (52), 213 (18), 255 (48), 267 (17), 282 (16), 296 (16), 351 (10), 379 (12), 394 (100) & Isobe et al. (2002) \\
\hline Stigmastadienone 2 & 410 & 174 (100), 269 (13), 395 (13), $410(37)$ & \\
\hline$\beta$-Sitosterol (Ac) 3 & 456 & 145 (38), 147 (59), 213 (20), 255 (30), 275 (24), 288 (29), 381 (28), 396 (100) & Isobe et al. (2002) \\
\hline Glutinone 4 & 424 & 150 (22), 189 (37), 205 (30), 245 (10), 259 (100), 274 (57) & Shiojima et al. (1992) \\
\hline Taraxerol (Ac) 5 & 468 & 189 (42), 204 (100), 218 (25), 257 (17), 269 (27), 329 (22), 344 (31), 453 (7), 468 (10) & Shiojima et al. (1992); Lavrieux et al. (2011) \\
\hline Germanicol (Ac) 6 & 468 & 161 (15), 177 (81), 189 (100), 204 (90), 205 (45), 218 (31), 231 (13), 393 (3), 408 (4), 453 (15), 468 (18) & Shiojima et al. (1992); Oyo-Ita et al. (2010) \\
\hline Lupeol (Ac) 7 & 468 & 175 (38), 189 (100), 203 (37), 204 (40), 218 (28), 249 (17), 453 (6), 468 (19) & Shiojima et al. (1992); Stiti et al. (2007) \\
\hline Friedelin 8 & 426 & 109 (89), 123 (100), 125 (52), 163 (56), 191 (48), 205 (45), 246 (44), 273 (39), 302 (17), 341 (8), 411 (17), 426 (23) & Budzikiewicz et al. (1963) \\
\hline$\alpha$-Amyrin (Ac) 9 & 468 & 189 (41), 203 (28), 218 (100), 249 (5), 408 (3), 468 (4) & Shiojima et al. (1992); Lavrieux et al. (2011) \\
\hline Bauerenyl acetate $\mathbf{1 0}$ & 468 & 229 (100), 241 (20), 289 (94), 301 (12), 393 (7), 408 (7), 453 (8), 468 (5) & Lavrieux et al. (2011) \\
\hline Betulin (di-Ac) 11 & 526 & 175 (24), 187 (64), 189 (100), 191 (59), 203 (41), 216 (28), 249 (6), 393 (7), 423 (19), 451 (9), 466 (33), 526 (1) & Stiti et al. (2007) \\
\hline Miliacin 12 & 440 & $175(32), 177$ (64), 189 (100), $204(80), 218(36), 231$ (22), 393 (3), 425 (18), 440 (18) & Jacob et al. (2005) \\
\hline Isosawamilletin $\mathbf{1 3}$ & 440 & 175 (7), 189 (14), 203 (50), 218 (100), 440 (1) & Jacob et al. (2005) \\
\hline
\end{tabular}

${ }^{a}$ Alcohols analyzed as acetate derivatives (Ac). 


\section{Table S2}

${ }^{14} \mathrm{C}$ age ( $\mathrm{BP}$ and cal. $\left.\mathrm{BC} / \mathrm{AD}^{\mathrm{b}}\right)$ and fraction modern $\left(\mathrm{F}^{14} \mathrm{C}\right)^{\mathrm{c}}$ determined for soil organic matter $(\mathrm{SOM})$, lipid extracts $(\mathrm{LE})$ and isolated miliacin $(\mathbf{1 2})$ from selected silo samples $(\mathrm{AL})$ and loess substrate samples (LS).

\begin{tabular}{|c|c|c|c|c|c|c|}
\hline Sample & Number (ETH) & Amount of soil & 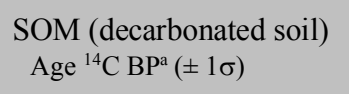 & $\mathrm{F}^{14} \mathrm{C}^{\mathrm{g}}( \pm 1 \sigma)^{\mathrm{c}}$ & Cal. age ${ }^{14} \mathrm{C}(68.2 \%)^{\mathrm{b}}$ & Cal. age ${ }^{14} \mathrm{C}(95.4 \%)^{\mathrm{b}}$ \\
\hline 1330.AL6 ${ }^{\mathrm{d}}$ & ЕTH-65607 & $230 \mathrm{mg}$ & $3042( \pm 28)$ & $0.762( \pm 0.003)$ & $\begin{array}{c}1381-1343 \mathrm{BC}^{\mathrm{f}}(27.0 \%) \\
1307-1260 \mathrm{BC}(37.6 \%) \\
1242-1235 \mathrm{BC}(3.6 \%)\end{array}$ & $1396-1218$ BC (95.4\%) \\
\hline 1330.LS & ETH-65606 & $140 \mathrm{mg}$ & $7597( \pm 54)$ & $0.388( \pm 0.003)$ & $6492-6412$ BC (68.2\%) & $6589-6378$ BC (95.4\%) \\
\hline 1763.AL2 ${ }^{\mathrm{d}}$ & ETH-66449 & $200 \mathrm{mg}$ & $3022( \pm 23)$ & $0.687( \pm 0.002)$ & $1366-1221 \mathrm{BC}(68.2 \%)$ & $1386-1195$ BC (95.4\%) \\
\hline $4564 . \mathrm{AL}^{\mathrm{e}}$ & ETH-65605 & $145 \mathrm{mg}$ & $2072( \pm 27)$ & $0.773( \pm 0.003)$ & $\begin{array}{l}154-136 \text { ВC }(11.5 \%) \\
114-46 \text { BC }(56.7 \%)\end{array}$ & $\begin{array}{c}175-36 \text { BC }(91.8 \%) \\
31-20 \text { BC }(1.7 \%) \\
12-1 \text { BC }(1.9 \%)\end{array}$ \\
\hline Sample & Number (ETH) & Amount of LE & $\begin{array}{c}\text { LE } \\
\text { Age }{ }^{14} \mathrm{C} \mathrm{BP}( \pm 1 \sigma)\end{array}$ & $\mathrm{F}^{14} \mathrm{C}( \pm 1 \sigma)$ & Cal. age ${ }^{14} \mathrm{C}(68.2 \%)$ & Cal. age ${ }^{14} \mathrm{C}(95.4 \%)$ \\
\hline 1330.AL6 & ETH-59648 & $1.3 \mathrm{mg}$ & $2806( \pm 28)$ & $0.705( \pm 0.002)$ & $996-922$ BC (68.2\%) & $1044-896$ BC (95.4\%) \\
\hline 1330.LS ${ }^{\mathrm{h}}$ & ETH-63066 & $0.8 \mathrm{mg}$ & $122( \pm 27)$ & $0.985( \pm 0.003)$ & $\begin{array}{c}1685-1707 \mathrm{AD}(12.3 \%) \\
1719-1732 \mathrm{AD}(7.0 \%) \\
1808-1826 \mathrm{AD}(9.4 \%) \\
1833-1885 \mathrm{AD}(31.5 \%) \\
1913-1927 \mathrm{AD}(8.0 \%)\end{array}$ & $\begin{array}{l}\text { 1679-1764 } \mathrm{AD}(32.7 \%) \\
1801-1897 \mathrm{AD}(47.8 \%) \\
1902-1940 \mathrm{AD}(14.9 \%)\end{array}$ \\
\hline 4564.AL8 & ETH-63064 & $1.5 \mathrm{mg}$ & $1784( \pm 25)$ & $0.801( \pm 0.003)$ & $\begin{array}{l}215-260 \mathrm{AD}(37.9 \%) \\
280-325 \mathrm{AD}(30.3 \%)\end{array}$ & $\begin{array}{l}138-264 \mathrm{AD}(61.0 \%) \\
274-330 \mathrm{AD}(34.4 \%)\end{array}$ \\
\hline Sample & Number (ETH) & Amount of $\mathbf{1 2}$ & $\begin{array}{r}\text { Miliacin (12) } \\
\text { Age }{ }^{14} \mathrm{C} \mathrm{BP}( \pm 1 \sigma)\end{array}$ & $\mathrm{F}^{14} \mathrm{C}( \pm 1 \sigma)$ & Cal. age ${ }^{14} \mathrm{C}(68.2 \%)$ & Cal. age ${ }^{14} \mathrm{C}(95.4 \%)$ \\
\hline 1330.AL2 & ETH-59645 & $40 \mu \mathrm{g}$ & $3151( \pm 66)$ & $0.676( \pm 0.006)$ & $\begin{array}{l}1501-1381 \mathrm{BC}(55.4 \%) \\
1342-1306 \mathrm{BC}(12.8 \%)\end{array}$ & $\begin{array}{c}1607-1582 \mathrm{BC}(2.1 \%) \\
1560-1259 \mathrm{BC}(92.8 \%) \\
1242-1234 \mathrm{BC}(0.5 \%)\end{array}$ \\
\hline 1330.AL6 & ETH-59646 & $27 \mu \mathrm{g}$ & $2999( \pm 87)$ & $0.688( \pm 0.008)$ & $\begin{array}{l}1386-1340 \text { BC }(11.5 \%) \\
1317-1116 \text { BC }(56.7 \%)\end{array}$ & $1438-996$ BC (95.4\%) \\
\hline 1330.AL10 & ETH-59647 & $38 \mu \mathrm{g}$ & $3175( \pm 255)$ & $0.674( \pm 0.021)$ & $1750-1110 \mathrm{BC}(68.2 \%)$ & $\begin{array}{l}2124-2091 \text { BC }(0.7 \%) \\
2044-826 \text { BC }(94.7 \%)\end{array}$ \\
\hline 1763.AL2 & ETH-63065 & $15 \mu \mathrm{g}$ & $2967( \pm 127)$ & $0.691( \pm 0.011)$ & $\begin{array}{c}1381-1342 \mathrm{BC}(6.9 \%) \\
1307-1015 \mathrm{BC}(61.3 \%)\end{array}$ & $\begin{array}{c}1496-1474 \text { BC }(1.0 \%) \\
1461-894 \text { BC }(93.5 \%) \\
872-852 \text { BC }(0.8 \%)\end{array}$ \\
\hline 4564.AL8 & ETH-65602 & $300 \mu \mathrm{g}$ & $1906( \pm 50)$ & $0.789( \pm 0.005)$ & $26-209 \mathrm{AD}(68.2 \%)$ & $19 \mathrm{BC}-236 \mathrm{AD}(95.4 \%)$ \\
\hline
\end{tabular}

${ }^{\mathrm{a} B P}$ : "Before Present" where the year 1950 , when nuclear weapons testing changed the ${ }^{14} \mathrm{C}$ concentration in the atmosphere, is the reference (0 BP); ${ }^{b}$ the radiocarbon content within the atmosphere having varied over time, the calibration atmospheric curve used includes important fluctuations (IntCal13; Reimer et al., 2013). Hence, the ${ }^{14} \mathrm{C}$ age expressed in BP (i.e. before $1950 \mathrm{AD}$ ) can be associated with several possible ranges of time, the calibration atmospheric curve used includes important fluctuations (IntCal13; Reimer et al., 2013). Hence, the ${ }^{14} \mathrm{C}$ age expressed in $\mathrm{BP}$ (i.e. before $1950 \mathrm{AD}$ ) can be associated with several possible ranges of
time for the samples (cal. ${ }^{14} \mathrm{C}$ age $\left.\mathrm{BC}\right) ;{ }^{\mathrm{c}} \mathrm{F}^{14} \mathrm{C}$ : fraction modern, $\mathrm{F}^{14} \mathrm{C}=\exp \left(-{ }^{14} \mathrm{Cage} / 8033\right)$; see Reimer et al. (2004); ${ }^{\mathrm{d}}$ measure performed on soil sample after extraction and decarbonation; ${ }^{\mathrm{e}}$ measure achieved on time for the samples (cal. ${ }^{14} \mathrm{C}$ age $\left.\mathrm{BC}\right) ;{ }^{\mathrm{C}} \mathrm{F}^{14} \mathrm{C}$ : fraction modern, $\mathrm{F}^{14} \mathrm{C}=\exp \left(-{ }^{-4} \mathrm{Cage} / 8033\right)$; see Reimer et al. $(2004) ;{ }^{\circ}$ measure perf
decarbonated soil sample; ${ }^{\mathrm{B}} \mathrm{BC}$ : before Christ; ${ }^{\mathrm{g}} \mathrm{AD}$ : Anno Domini; ${ }^{\mathrm{h}}$ sample likely contaminated by input from recent organic material. 


\section{References}

Budzikiewicz, H., Wilson, J.M., Djerassi, C., 1963. Mass spectrometry in structural and stereochemical problems. XXXII. Pentacyclic triterpenes. Journal of the American Chemical Society 85, 3688-3699.

Isobe, K.O., Tarao, M., Zakaria, M.P., Chiem, N.H., Minh, L.Y., Takada, H., 2002. Quantitative application of fecal sterols using gas chromatography-mass spectrometry to investigate fecal pollution in tropical waters: Western Malaysia and Mekong Delta, Vietnam. Environmental Science \& Technology 36, 4497-4507.

Jacob, J., Disnar, J.-R., Boussafir, M., Albuquerque, A.L.S., Sifeddine, A., Turcq, B., 2005. Pentacyclic triterpene methyl ethers in recent lacustrine sediments (Lagoa do Caçó, Brazil). Organic Geochemistry 36, 449-461.

Lavrieux, M., Jacob, J., Le Milbeau, C., Zocatelli, R., Masuda, K., Bréheret, J.-G., Disnar, J.-R., 2011. Occurrence of triterpenyl acetates in soil and their potential as chemotaxonomical markers of Asteraceae. Organic Geochemistry 42, 1315-1323.

Oyo-Ita, O.E., Ekpo, B.O., Oros, D.R., Simoneit, B.R.T., 2010. Occurrence and sources of triterpenoid methyl ethers and acetates in sediments of the cross-river system, Southeast Nigeria. International Journal of Analytical Chemistry, doi:10.1155/2010/502076.

Reimer, P.J., Brown, T.A., Reimer, R.W., 2004. Discussion: reporting and calibration of post-bomb ${ }^{14} \mathrm{C}$ data. Radiocarbon 46, 1299-1304.

Shiojima, K., Arai, Y., Masuda, K., Takase, Y., Ageta, T., Ageta, H., 1992. Mass spectra of pentacyclic triterpenoids. Chemical and Pharmaceutical Bulletin 40, 1683-1690.

Stiti, N., Triki, S., Hartmann, M.-A., 2007. Formation of triterpenoids throughout Olea europaea fruit ontogeny. Lipids 42, 55-67. 